It is made available under a CC-BY-NC-ND 4.0 International license .

Viral cultures for COVID-19 infectivity assessment - a systematic review In: Analysis of the Transmission Dynamics of COVID-19: An Open Evidence Review

\title{
Viral cultures for COVID-19 infectivity assessment - a systematic review (Update 4)
}

\author{
Jefferson $\mathrm{T}^{1}$; Spencer $E A^{1}$; Brassey $\mathrm{J}^{2}$; Heneghan $\mathrm{C}^{1}$.
}

\section{Affiliations}

\section{Nuffield Department of Primary Care Health Sciences, University of Oxford, Radcliffe Observatory Quarter, Oxford, OX2 6GG}

\section{Trip Database Ltd}

Keywords: Covid-19; mode of transmission, viral culture; symptom onset to test date; polymerase chain reaction; SARS-CoV-2; infectivity.

Joint corresponding authors:

Jefferson (tom-jefferson@conted.ox.ac.uk)

Heneghan (Carl.heneghan@phc.ox.ac.uk)

\section{Summary}

Objective to review the evidence from studies comparing SARS-CoV-2 culture, the best indicator of current infection and infectiousness with the results of reverse transcriptase polymerase chain reaction (RT-PCR).

Methods We searched LitCovid, medRxiv, Google Scholar and the WHO Covid-19 database for Covid-19 using the terms 'viral culture' or 'viral replication' and associated synonyms up to 10 September 2020. We carried out citation matching and included studies reporting attempts to culture or observe SARS-CoV-2 matching with cutoffs for RT-PCR positivity. One reviewer extracted data for each study and a second reviewer checked end edited the extraction and summarised the narratively by sample: fecal, respiratory, environment or mixed.

Where necessary we wrote to corresponding authors of the included or background papers for additional information. We assessed quality using a modified QUADAS 2 risk of bias tool.

This review is part of an Open Evidence Review on Transmission Dynamics of COVID-19. Summaries of the included studies and the protocol ( $v 1$ ) are available at: https://www.cebm.net/evidencesynthesis/transmission-dynamics-of-covid-19/. Searches are updated every 2 weeks. This is the fourth version of this review that was first published on the 4th of August and updated on the 21t of August

Results We included 29 studies reporting culturing or observing tissue invasion by SARS-CoV in sputum, naso or oropharyngeal, urine, stool, blood and environmental samples from patients diagnosed with Covid19. The data are suggestive of a relation between the time from collection of a specimen to test, cycle threshold and symptom severity. The quality of the studies was moderate with lack of standardised reporting. 
41 Twelve studies reported that $\mathrm{Ct}$ values were significantly lower and log copies higher in samples producing live virus culture. Five studies reported no growth in samples based on a Ct cut-off value. These values ranged from $\mathrm{CT}>24$ for no growth to $\mathrm{Ct} \geq 34$. Two studies report a strong relationship between $\mathrm{Ct}$ value and ability to recover infectious virus and that the odds of live virus culture reduced by $33 \%$ for every one unit increase in Ct. A cut-off RT-PCR Ct > 30 was associated with non-infectious samples. One study that analysed the NSP, N and E gene fragments of the PCR result reported different cut-off thresholds depending on the gene fragment analysed. The duration of RNA shedding detected by PCR was far longer compared to detection of live culture. Six out of eight studies reported RNA shedding for longer than 14 days. Yet, infectivity declines after day 8 even among cases with ongoing high viral loads. A very small proportion of people re-testing positive after hospital discharge or with high $\mathrm{Ct}$ are likely to be infectious.

\section{Conclusion}

53 Prospective routine testing of reference and culture specimens are necessary for each country involved in the pandemic to establish the usefulness and reliability of PCR for Covid-19 and its relation to patients' factors. Infectivity is related to the date of onset of symptoms and cycle threshold level. positives with possible segregation of large numbers of people who are no longer infectious and hence not a threat to public health. 


\section{Introduction}

The ability to make decisions on the prevention and management of COVID-19 infections rests on our capacity to identify those who are infected and infectious. In the absence of predictive clinical signs or symptoms ${ }^{1}$, the most widely used means of detection is molecular testing using Reverse Transcriptase quantitative Polymerase Chain Reaction (RT-qPCR) ${ }^{23}$. The test amplifies genomic sequences identified in samples. As it is capable of generating observable signals from small samples, it is very sensitive. Amplification of genomic sequence is measured in cycle thresholds $(\mathrm{Ct})$. There appears to be a correlation between $\mathrm{Ct}$ values from respiratory samples, symptom onset to test (STT) date and positive viral culture. The lower the Ct value and the shorter the STT, the higher the infectivity potential ${ }^{4}$. Whether probing for sequences or whole genomes ${ }^{5}$, in the diagnosis of Covid-19 a positive RT-qPCR cannot tell you whether the person is infectious or when the infection began, nor the provenance of the genetic material. Very early in the COVID-19 outbreak it was recognised that cycle threshold values may be a proxy for quantitative measure of viral load, but correlation with clinical progress and transmissibility was not yet known $^{6}$. A positive result indicates that a person has come into contact with the genomic sequence or some other viral antigen at some time in the past. However, presence of viral genome on its own is not sufficient proof of infectivity and caution is needed when evaluating the infectivity of specimens simply based on the detection of viral nucleic acids ${ }^{5}$. In addition, viral genomic material can be still be present weeks after infectious viral clearance. ${ }^{7}$ Like all tests, RT-qPCR requires validation against a gold standard. In this case isolation of a whole virion (as opposed to fragments) and proof that the isolate is capable of replicating its progeny in culture cells is the closest we are likely to get to a gold standard. ${ }^{8}$ The inability of PCR to distinguish between the shedding of live virus or of viral debris, means that is cannot measure a person's viral load (or quantity of virus present in a person's excreta). which have attempted viral culture. There are objective difficulties in doing such cultures such as the requirement for a level III laboratory, avoidance of contamination, time and the quality of the specimens as well as financial availability of reagents and culture media to rule out the presence of other pathogens. As viral culture represents the best indicator of infection and infectiousness, we set out to review the evidence on viral culture compared to PCR, and report the results of those studies attempting viral culture regardless of source (specimen type) of the sample tested.

\section{Methods}

We searched four main databases: LitCovid, medRxiv, Google Scholar and the WHO Covid-19 database for Covid-19 using the terms 'viral culture' or 'viral replication' and associated synonyms. Searches were last updated on 10 September 2020. Searches are conducted on a per calendar month basis and for databases which do not support such date granularity, the date of publication is approximated. For articles that looked 
101 We included studies reporting attempts to culture SARS-CoV-2 and those which also estimated the infectiousness of the isolates or observed tissue invasion by SARS CoV-2. One reviewer extracted data for each study and a second review checked end edited the extraction. We tabulated the data and summarised data narratively by mode of sample: fecal, respiratory, environment or mixed.

Where necessary we wrote to corresponding authors of the included or background papers for additional information. We assessed quality using a modified QUADAS 2 risk of bias tool. We simplified the tool as the included studies were not designed as primary diagnostic accuracy studies. ${ }^{9}$

108 This review is part of an Open Evidence Review on Transmission Dynamics of COVID-19. Summaries of the included studies and the protocol ( $\mathrm{v} 1)$ are available at: https://www.cebm.net/evidencesynthesis/transmission-dynamics-of-covid-19/. Searches are updated every 2 weeks.

This is the fourth update of this review with the addition of four studies identified in the two weeks since the 113 last update.

\section{Results}

116 We identified 145 articles of possible interest and after screening full texts included 29 (see PRISMA ${ }^{10}$ flow

117 chart - Figure 1). We identified one unpublished study which was not included as no permission to do so was 118 given by the authors. The salient characteristics of each included study are shown in Table 1.

119 All included studies were case series of moderate quality (Table 2. Quality of included studies). We could 120 not identify a protocol for any of the studies. All the included studies had been either published or were 121 available as preprints. All had been made public in 2020. We received five responses from authors regarding 122 clarifying information (see Acknowledgments).

\section{Studies using fecal samples}

125 Nine studies assessed viral viability from fecal samples which were positive for SARS-CoV-2 based on RT-

126 PCR result ${ }^{11-13}$ 14-19. One study reported infecting ferrets with stool supernatant ${ }^{11}$, two reported visual growth 127 in tissue ${ }^{12} 20$ and five reported achieving viral replication ${ }^{13-16}$. One laboratory study ${ }^{21}$ found that SARS-CoV-2 128 infected human small intestinal organoids.

\section{Studies using respiratory samples}

131 Sixteen studies on respiratory samples reported achieving viral isolation $4211232414151625-28$ 1929-31. One

132 study assessed 90 nasopharyngeal samples and cultured 26 of the samples, and positive cultures were only 133 observed up to day eight post symptom onset; ${ }^{4}$ another study obtained 31 cultures from 46 nasopharyngeal 134 and oropharyngeal samples; ${ }^{23}$ while 183 nasopharyngeal and sputum samples produced 124 cases in 135 which a cytopathic effect was observed although the denominator of samples taken was unclear ${ }^{32}$. Another 136 study in health care workers in UK hospitals isolated one SARS Cov-2 from nineteen specimens in a 137 situation of low viral circulation. ${ }^{27}$ 
Viral cultures for COVID-19 infectivity assessment - a systematic review

In: Analysis of the Transmission Dynamics of COVID-19: An Open Evidence Review

139 Two more studies reported a clear correlation between symptoms onset, date of sampling, Ct and likelihood

140 of viral culture. ${ }^{2526}$

142 L'Huillier and colleagues ${ }^{28}$ sampled nasopharyngeal swabs in 638 patients aged less than 16 years in a

143 Geneva Hospital: 23 (3.6\%) tested positive for SARS CoV-2 - median age of 12 years and 12 (52\% were

144 culture positive). The Ct was around 28 for the children whose samples grew viable viruses. Gniazdowski ${ }^{29}$

145 probably assessed 161 nasopharyngeal specimens. A positive culture was associated with $\mathrm{Ct}$ values of 18.8

$146 \pm 3.4$. Infectious viral shedding occurred in specimens (a $\mathrm{Ct} \geq 23$ yielded $8.5 \%$ of virus isolates).

147

148 Basile and colleagues ${ }^{30}$ found a culture positivity rate of $24 \%$, which was significantly more likely to be

149 positive in ICU patients compared with other inpatients or outpatients.

150 A report by the Korean Centres for Disease Control failed to grow live viruses from 108 respiratory samples

151 from "re-positives" i.e. people who had tested positive after previously testing negative ${ }^{33}$

152

153 Ladhani ${ }^{31}$ and colleagues reported a successful culture rate of out 31 of 86 RT-PCR positive naso-

154 pharyngeal samples from six nursing home in London.

155 The largest number of positive culture came from the La Scola group publications ${ }^{32}$ with 1941 positive

156 cultures from 3790 samples.

157

\section{Studies using environmental samples}

159 Two possible positive cultures were obtained from 95 environmental samples in one study that assessed the 160 aerosol and surface transmission potential of SARS-CoV-2 ${ }^{34}$. Zhou and colleagues reported on samples

161 taken from seven areas of a large London hospital. Despite apparent extensive air and surface

162 contamination of the hospital environment, no infectious samples were grown ${ }^{35}$. For air samples, $2 / 31$

163 (6.4\%) were positive and 12/31 (39\%) suspect for SARS-CoV-2 RNA but no virus was cultured. Similarly,

16491 of 218 surface samples were suspect (42\%) or 23 positive (11\%) for SARS-CoV-2 RNA but no virus was

165 cultured. The authors noted that a cut-off RT-PCR Ct $>30$ was associated with non-infectious specimens.

166

167 Ahn and colleagues ${ }^{36}$ failed to grow live virus from an unspecified number of air samples in isolation rooms

168 of patients with severe Covid-19 but were able to grow virus from swabs of hand rails, and the external

169 surfaces of intubation cannulae.

\section{Mixed sources}

172

Some of the studies labelled as mixed source samples are also reported in individual provenance breakdown in this text because of lack of clarity of the text. 
179

180

181

182

183

184

185

186

187

188

189

190

191

192

193

194

195

196

197

198

199

200

201

202

203

204

205

206

207

208

209

210

211

212

213

214

215

216

217

218

Viral cultures for COVID-19 infectivity assessment - a systematic review

In: Analysis of the Transmission Dynamics of COVID-19: An Open Evidence Review who reported isolation live virus from a stool sample also reported that from of an unreported number of nasopharyngeal, oropharyngeal, saliva, sputum and stool samples, one viral culture was achieved: ferrets inoculated with these samples became infected; SARS-CoV-2 was isolated from the nasal washes of the two urine-treated ferrets and one stool-treated ferret ${ }^{11}$. An unreported number of samples from saliva, nasal swabs, urine, blood and stool collected from nine Covid-19 patients produced positive cultures and a possible specimen stool culture ${ }^{14}$. One study showed that from nine nasopharyngeal, oropharyngeal, stool, serum and urine samples, all nine were culturable, including two from non-hospitalised Covid-19 patients ${ }^{15}$.

Yao and colleagues cultured viable viral isolates from seven sputum samples, three stool samples and one nasopharyngeal sample of 11 patient aged 4 months to 71 years, indicating that the SARS-CoV-2 is capable of replicating in stool samples as well as sputum and the nasopharynx. ${ }^{16}$ All samples had been taken within 5 days of symptom onset. The authors also report a relationship between viral load (copy thresholds) and cytopathic effect observed in infected culture cells. ${ }^{37}$

Kim and colleagues reported no viral growth from and unclear number of serum, usirne and stool samples despite collection very soon after admission ${ }^{17}$. Lu and colleagues also reported no viral growth, however their specimens were from 87 cases tested "re-positive". ${ }^{18}$

Young and colleagues ${ }^{19}$ from Singapore had 21 positive cultures from 19 hospitalised patients in Singapore. No virus was isolated from samples with a Ct value $>30$, or when the sample was collected $>14$ days after symptoms onset. All positive cultures came from naso-pharyngeal samples, none of the 24 urine or 35 stool samples exhibited viral growth

\section{Blood cultures}

In one study by Andersson ${ }^{38}$ et al 20 RT-PCR positive serum samples were selected at random from a Covid-19 sample bank, representing samples from 12 individual patients (four individuals were represented at two timepoints), collected at 3 to 20 days following onset of symptoms. None of the 20 serum samples produced a viral culture

\section{Post mortem study}

One study on alveolar samples from 68 elderly deceased gre iable virus from 6 out 6 different samples, in one case on day 26 from symptom onset. ${ }^{39}$

\section{Duration of viral shedding}

Nine studies report on the duration of viral shedding as assessed by PCR for SARS-CoV-2 RNA 41120131415 132540 . The minimum duration of RNA shedding detected by PCR was seven days reported in Bullard, the maximum duration of shedding was 35 days after symptom onset in Qian. Seven out of eight studies reported RNA shedding for longer than 14 days (see Table 3).

Young et $\mathrm{al}^{19}$ reported that $91 \%$ of patients had ceased viral shedding by day 20 from symptom onset. 


\section{Duration of live viral culture detection}

221 The duration of live viral culture detection was much shorter than viral shedding. Wölfel et al ${ }^{14}$ reported that

222 virus could not be isolated from samples taken after day 8 even among cases with ongoing high viral loads

223 of approximately 105 RNA copies $/ \mathrm{mL}$.

Bullard et al similarly reported that SARS-CoV-2 Vero cell infectivity of respiratory samples from SARS-CoV2 positive individuals was only observed for RT-PCR $\mathrm{Ct}<24$ and symptom onset to test of $<8$ days ${ }^{4}$. culture was 4 days (Inter Quartile Range: 1 to 8$)^{25}$.

\section{The relationship between RT-PCR results and viral culture of SARS-CoV-2}

232 Fifteen studies attempted to quantify the relationship between cycle threshold (Ct) and likelihood of culturing

233 live virus 4123213151416252627 28-31. Table 4 shows that nine studies analysed the relationship between $\mathrm{Ct}$

234 values and live viral culture $4532 \underline{25272930} 3119$ and three quantified the mean log copies of detected virus and

235 live culture ${ }^{526} 28$. All reported that Ct were significantly lower and log copies were significantly higher in those

236 with live virus culture. Five studies reported no growth in samples based on a Ct cut-off value $e^{4527} \cdot{ }^{1931}$ These

237 values for no growth ranged from CT $>24^{4}$ to $\mathrm{Ct} \geq 35^{31}$. was $8.3 \%$ (95\% Cl: $2.8 \%-18.4 \%)$. All donors above the $\mathrm{Ct}$ threshold of $35(\mathrm{n}=5)$ with live culture were symptomatic.

The study in London nursing homes by Ladhani and colleagues found no correlation between Ct values with presence or absence of symptoms in either residents or staff ${ }^{31}$, although nearly $50 \%$ of both categories were asymptomatic.

Huang and colleagues ${ }^{5}$ analysed the NSP, N and E gene fragments of the PCR result, which reported different cut-off thresholds depending on the gene fragment analysed ${ }^{5}$. No growth was found for the NSP 12 fragment at $\mathrm{Ct}>31.47$, whereas the value was higher for the $\mathrm{N}$ gene fragment at $>35.2$.

Bullard et al ${ }^{4}$ reported a reduction in the odds ratio for culturing live virus of 0.64 for every one unit increase in $\mathrm{Ct}(95 \% \mathrm{Cl} 0.49$ to $0.84, \mathrm{p}<0.001)$. Similar to Bullard and colleagues, Singanayagam ${ }^{22}$ reported a strong relationship between $\mathrm{Ct}$ value and ability to recover infectious virus: estimated OR of recovering infectious

254 virus decreased by 0.67 for each unit increase in Ct value ( $95 \% \mathrm{Cl}: 0.58-0.77)$. This value is very close to 255 that of other empirical studies (an increased Ct of 0.58 per day since symptoms started) ${ }^{41}$ 
Viral cultures for COVID-19 infectivity assessment - a systematic review

In: Analysis of the Transmission Dynamics of COVID-19: An Open Evidence Review Young et $\mathrm{al}^{19}$ reported no viral isolation from samples where the Ct value was $>30$, or when the sample was collected >14 days after symptoms onset.

260

261

\section{Discussion}

262 Society is attempting to interrupt transmission of SARS-CoV-2 by identifying and isolating those who are sick

263 and those who are infectious. As there are no Covid-19-specific mass treatments or preventive measures,

264 such a strategy relies on our capability to identify infected and infectious persons with a reasonable amount

265 of certainty to avoid isolation of those who pose little threat to the public health. An increasing body of

266 evidence shows that such identification cannot be accurately achieved through the simplistic division of

267 those who test positive and who do not, on the basis of the results of RT-PCR. The sensitivity and specificity

268 of RT-PCR needs comparing to the gold standard of infectiousness: the capacity to grow live virus from a

269 specimen.

270

Some of the authors of the studies in our review have attempted and successfully achieved culture of SARSCoV-2 in the laboratory, using a range of respiratory, fecal or environmentally collected samples. However the simplistic dichotomous division into positive/negative is insufficient to accurately identify infectiousness as detection of viral RNA cannot support an inference of contagiousness ${ }^{42}$. The evidence shows that there is a positive relationship between lower cycle count threshold, likelihood of positive viral culture ${ }^{43}$ and date of symptom onset. Nowhere can this be seen as clearly as in the two studies assessing the infectiousness of "re-positives", i.e. those COVID-19 cases who had been discharged from hospital after testing negative repeatedly and then testing positive after discharge: $L u 2020^{18}$, Korean $\mathrm{CDC}^{33}$. In a very tightly designed and argued study Lu and colleagues tested four hypotheses for the origin of "repositives" ${ }^{\prime 18}$. After discarding the first two (re-infection and latency) on the basis of their evidence, they reached the conclusions that the most plausible explanations were either contamination of the sample by extraneous material or identification in the sample of minute and irrelevant particles of SARS-CoV-2 debris representing virus long neutralised by the immune system.

284 Both explanations fit the facts, the others do not. It is very likely that a huge expansion in testing capability requires training protocols and precautions to avoid poor laboratory practice which are simply not possible in the restricted times of a pandemic. We equally know that weak positives (those with high $\mathrm{Ct}$ ) are unlikely to be infectious, as a whole live virus is the prime requirement for transmission, not the fragments identified by

\section{PCR.}

289 The purpose of viral testing is to assess the relation of the micro-organism and hazard to humans, i.e. its

290 clinical impact on the individual providing the sample for primary care and the risk of transmission to others

291 for public health. PCR on its own is unable to provide such answers. When interpreting the results of RT-

292 PCR it is important to take into consideration the clinical picture, the cycle threshold value, the number of 293 days from symptom onset to test (STT) and the specimen donor's age ${ }^{4442} 43$. Several of our included studies 294 assessed the relationship of these variables and there appears to be a time window during which shedding is 295 at its highest with low cycle threshold and higher possibility of culturing a live virus, with viral load and 296 probability of growing live virus of SARS-CoV2 peaking much sooner than that of SARS CoV-1 or MERS$297 \mathrm{CoV}^{42}$. We propose that further work should be done on this with the aim of constructing a calibrating 
Viral cultures for COVID-19 infectivity assessment - a systematic review

In: Analysis of the Transmission Dynamics of COVID-19: An Open Evidence Review

298

299

300

301

302

303

304

305

306

307

308

309

310

311

312

313

314

315

316

317

318

319

320

321

322

323

324

325

326

327

328

329

330

331

332

333

334

335

336

We are unsure whether SARS CoV-2 methods of cell culture have been standardised. Systems can vary depending upon the selection of the cell lines; the collection, transport, and handling of and the maintenance of viable and healthy inoculated cells $\mathrm{s}^{49}$. We therefore recommend that standard methods for culture should be urgently developed and external quality assessment schemes be extended to to all laboratories offering testing for SARS CoV2. ${ }^{50}$. If identification of viral infectivity relies on visual inspection of cytopathogenic effect, then a reference culture of cells must also be developed to test recognition against infected cells. Viral culture may not be appropriate for routine daily results, but specialized laboratories should rely on their own ability to use viruses as controls, perform complete investigations when needed, and store representative clinical strains whenever possible ${ }^{49}$. In the absence of culture, ferret inoculation of specimen washings and antibody titres could also be used. It may be impossible to produce a universal Cycle threshold value as this may change with circumstances (e.g. hospital, community, cluster and symptom level), laboratory methods ${ }^{51}$ and the current evidence base is thin.

We suggest the WHO produce a protocol to standardise the use and interpretation of PCR and routine use of culture or animal model to continuously calibrate PCR testing, coordinated by designated Biosafety Level III laboratory facilities with inward directional airflow ${ }^{52}$. Further studies with standardised methods ${ }^{51}$ and reporting are needed to establish the magnitude and reliability of this association.

The results of our review are similar to those of the scoping review by Byrne and colleagues on infectivity periods $^{53}$ and those of the living review by Cevick and colleagues ${ }^{42}$. Although the inclusion criteria are narrower than ours, the authors reviewed 79 studies on the dynamics, load and shedding for SARS CoV-1, MERS and SARS CoV-2 from symptoms onset. They conclude that although SARS-CoV-2 RNA shedding in respiratory (up to 83 days) and stool (35 days) can be prolonged, duration of viable virus is relatively shortlived (up to a maximum of 8 days from symptoms onset). Results that are consistent with Bullard et al who found no growth in samples with a cycle threshold greater than 24 or when symptom onset was greater than

www.cebm.net/evidence-synthesis 
Viral cultures for COVID-19 infectivity assessment - a systematic review

In: Analysis of the Transmission Dynamics of COVID-19: An Open Evidence Review 8 days, and Wölfel et al ${ }^{14}$ who reported that virus could not be isolated from samples taken after day 8 even among cases with ongoing high viral loads. The review by Rhee and colleagues also reaches conclusion similar to ours. ${ }^{43}$

The evidence is increasingly pointing to the probability of culturing live virus being related to the amount of

342 viral RNA in the sample and, therefore, inversely related to the cycle threshold. Thus, blanket detection of

343 viral RNA cannot be used to infer infectiousness. Length of excretion is also linked to age, male gender and

344 possibly use of steroids and severity of illness.

The limits of our review are the low number of studies of relatively poor quality with lack of standardised

347 reporting and lack of gold testing for each country involved in the pandemic. We plan to keep updating this review with emerging evidence.

\section{Conclusion}

351 The current data are suggestive of a relation between the time from collection of a specimen to test, copy 352 threshold, and symptom severity, but the quality of the studies limits drawing firm conclusions. We 353 recommend that a uniform international standard for reporting of comparative SARS-CoV-2 culture with 354 index test studies be produced. Particular attention should be paid to the relationship between the results of 355 testing, clinical conditions and the characteristics of the source patients, description of flow of specimens and 356 testing methods. Extensive training of operators and avoidance of contamination should take place on the 357 basis of fixed and internationally recognised protocols. Defining cut off levels predictive of infectivity should 358 be feasible and necessary for diagnosing viral respiratory infections using molecular tests ${ }^{54}$.

359 We will contact the corresponding authors of the 11 studies correlating Ct with likelihood of culture to assess 360 whether it is possible to aggregate data and determine a firm correlation to aid decision making.

\section{Acknowledgments}

364 Drs Susan Amirian, Siyuan Ding, Long Rong and Sravanthi Parasato and Bernard La Scola provided additional information for this brief. Dr Maryanne DeMasi helped with reference identification.

\section{Funding}

368 The review was partly funded by NIHR Evidence Synthesis Working Group project 380 and supported by the 369 Maria and David Willets foundation.

Disclaimer: The article has not been peer-reviewed. The views expressed in this commentary represent the 372 views of the authors and not necessarily those of the host institution, the NHS, the NIHR, or the Department 373 of Health and Social Care. The views are not a substitute for professional medical advice. It will be regularly 374 updated see the evidence explorer at https://www.cebm.net/evidence-synthesis/transmission-dynamics-ofcovid-19/ for regular updates to the evidence summaries and briefs. 


\section{Data Availability}

Viral cultures for COVID-19 infectivity assessment - a systematic review

In: Analysis of the Transmission Dynamics of COVID-19: An Open Evidence Review

378 All data included in the review are from publications or preprints. All extractions sheets with direct links to the

379 source paper are available from https://www.cebm.net/evidence-synthesis/transmission-dynamics-of-covid-

$380 \quad \underline{19}$

381

382

Authors:

383

Tom Jefferson is a Senior Associate Tutor and Honorary Research Fellow, Centre for Evidence-Based

384

Medicine, University of Oxford. Disclosure statement is here

385

386

Elizabeth Spencer is Epidemiology and Evidence Synthesis Researcher at the Centre for Evidence-Based

387

Medicine. (Bio and disclosure statement here)

388

389

Jon Brassey is the Director of Trip Database Ltd, Lead for Knowledge Mobilisation at Public Health Wales

390

(NHS) and an Associate Editor at the BMJ Evidence-Based Medicine.

391

392

393

Carl Heneghan is Professor of Evidence-Based Medicine, Director of the Centre for Evidence-Based Medicine and Director of Studies for the Evidence-Based Health Care Programme. (Full bio and disclosure statement here)

This work is licensed under a Creative Commons Attribution-NonCommercial 4.0 International License.

\section{References}

1. Wynants L, Van Calster B, Collins GS, et al. Prediction models for diagnosis and prognosis of covid-19: systematic review and critical appraisal. BMJ 2020;369:m1328. doi: 10.1136/bmj.m1328

2. Transmission of SARS-CoV-2: implications for infection prevention precautions. Scientific brief.

.2020

3. Report of the WHO-China Joint Mission on Coronavirus Disease 2019 (COVID-19) 16-24 February 2020. 2020

4. Bullard J, Dust K, Funk D, et al. Predicting infectious SARS-CoV-2 from diagnostic samples. LID 10.1093/cid/ciaa638 [doi] LID - ciaa638. (1537-6591 (Electronic))

5. Huang C-G, Lee K-M, Hsiao M-J, et al. Culture-Based Virus Isolation To Evaluate Potential Infectivity of Clinical Specimens Tested for COVID-19. J Clin Microbiol 2020;58(8):e01068-20. doi: $10.1128 / \mathrm{jcm} .01068-20$

6. Young BE, Ong SWX, Kalimuddin S, et al. Epidemiologic Features and Clinical Course of Patients Infected With SARS-CoV-2 in Singapore. (1538-3598 (Electronic))

7. Atkinson B, Petersen E. SARS-CoV-2 shedding and infectivity. The Lancet 2020;395(10233):1339-40. doi: 10.1016/S0140-6736(20)30868-0

8. Hematian A, Sadeghifard N, Mohebi R, et al. Traditional and Modern Cell Culture in Virus Diagnosis. Osong public health and research perspectives 2016;7(2):77-82. doi: 10.1016/j.phrp.2015.11.011 [published Online First: 2016/01/08]

9. Whiting PF, Rutjes Aw Fau - Westwood ME, Westwood Me Fau - Mallett S, et al. QUADAS-2: a revised tool for the quality assessment of diagnostic accuracy studies. (1539-3704 (Electronic)) 
Viral cultures for COVID-19 infectivity assessment - a systematic review

In: Analysis of the Transmission Dynamics of COVID-19: An Open Evidence Review

10. Moher D, Shamseer $L$, Clarke $M$, et al. Preferred reporting items for systematic review and metaanalysis protocols (PRISMA-P) 2015 statement. Syst Rev 2015;4(1):1-1. doi: 10.1186/2046-4053-4-1

11. Jeong HW, Kim S-M, Kim H-S, et al. Viable SARS-CoV-2 in various specimens from COVID-19 patients. Clin Microbiol Infect 2020:S1198-743X(20)30427-4. doi: 10.1016/j.cmi.2020.07.020

12. Wang W, Xu Y, Gao R, et al. Detection of SARS-CoV-2 in Different Types of Clinical Specimens. (15383598 (Electronic))

13. Xiao F SJ, Xu Y, Li F et al. Infectious SARS-CoV-2 in feces of patient with severe COVID-19. 2020 doi: https://doi.org/10.3201/eid2608.200681

14. Wölfel R, Corman VM, Guggemos W, et al. Virological assessment of hospitalized patients with COVID2019. Nature 2020;581(7809):465-69. doi: 10.1038/s41586-020-2196-x

15. Kujawski SA, Wong KK, Collins JP, et al. Clinical and virologic characteristics of the first 12 patients with coronavirus disease 2019 (COVID-19) in the United States. Nature Medicine 2020;26(6):861-68. doi: 10.1038/s41591-020-0877-5

16. Yao H, Lu X, Chen Q, et al. Patient-derived mutations impact pathogenicity of SARS-CoV-2. medRxiv 2020:2020.04.14.20060160. doi: 10.1101/2020.04.14.20060160

17. Kim JA-O, Kim HA-O, Lee EA-O, et al. Detection and Isolation of SARS-CoV-2 in Serum, Urine, and Stool Specimens of COVID-19 Patients from the Republic of Korea. (2210-9099 (Print))

18. Lu J, Peng J, Xiong Q, et al. Clinical, immunological and virological characterization of COVID-19 patients that test re-positive for SARS-CoV-2 by RT-PCR. EBioMedicine 2020;59 doi: 10.1016/j.ebiom.2020.102960

19. Young BE, Ong SWX, Ng LFP, et al. Viral dynamics and immune correlates of COVID-19 disease severity. Clinical Infectious Diseases 2020 doi: 10.1093/cid/ciaa1280

20. Qian Q, Fan L, Liu W, et al. Direct evidence of active SARS-CoV-2 replication in the intestine. Clinical Infectious Diseases 2020 doi: 10.1093/cid/ciaa925

21. Lamers MA-O, Beumer JA-O, van der Vaart JA-O, et al. SARS-CoV-2 productively infects human gut enterocytes. (1095-9203 (Electronic))

22. Huang C, Wang Y, Li X, et al. Clinical features of patients infected with 2019 novel coronavirus in Wuhan, China. The Lancet 2020;395(10223):497-506. doi: 10.1016/S0140-6736(20)30183-5

23. Arons MM, Hatfield KM, Reddy SC, et al. Presymptomatic SARS-CoV-2 Infections and Transmission in a Skilled Nursing Facility. New England Journal of Medicine 2020;382(22):2081-90. doi: 10.1056/NEJMoa2008457

24. La Scola B, Le Bideau M, Andreani J, et al. Viral RNA load as determined by cell culture as a management tool for discharge of SARS-CoV-2 patients from infectious disease wards. Eur I Clin Microbiol Infect Dis 2020;39(6):1059-61. doi: 10.1007/s10096-020-03913-9 [published Online First: 2020/04/27]

25. Singanayagam A, Patel M, Charlett A, et al. Duration of infectiousness and correlation with RT-PCR cycle threshold values in cases of COVID-19, England, January to May 2020. Eurosurveillance 2020;25(32):2001483. doi: doi:https://doi.org/10.2807/1560-7917.ES.2020.25.32.2001483

26. Perera RAPM, Tso E, Tsang OTY, et al. SARS-CoV-2 Virus Culture and Subgenomic RNA for Respiratory Specimens from Patients with Mild Coronavirus Disease. Emerging Infectious Disease journal 2020;26(11) doi: 10.3201/eid2611.203219

27. Brown CS, Clare K, Chand M, et al. Snapshot PCR surveillance for SARS-CoV-2 in hospital staff in England. Journal of Infection 2020;81(3):427-34. doi: 10.1016/j.jinf.2020.06.069

28. L'Huillier A, Torriani G, Pigny F, et al. Culture-Competent SARS-CoV-2 in Nasopharynx of Symptomatic Neonates, Children, and Adolescents. Emerging Infectious Disease journal 2020;26(10) doi: 10.3201/eid2610.202403

29. Gniazdowski V, Morris CP, Wohl S, et al. Repeat COVID-19 Molecular Testing: Correlation with Recovery of Infectious Virus, Molecular Assay Cycle Thresholds, and Analytical Sensitivity. medRxiv 2020:2020.08.05.20168963. doi: 10.1101/2020.08.05.20168963

30. Basile K, McPhie K, Carter I, et al. Cell-based culture of SARS-CoV-2 informs infectivity and safe deisolation assessments during COVID-19. medRxiv 2020:2020.07.14.20153981. doi: 10.1101/2020.07.14.20153981 
Viral cultures for COVID-19 infectivity assessment - a systematic review

In: Analysis of the Transmission Dynamics of COVID-19: An Open Evidence Review

31. Ladhani SN, Chow JY, Janarthanan R, et al. Investigation of SARS-CoV-2 outbreaks in six care homes in London, April 2020. EClinicalMedicine doi: 10.1016/j.eclinm.2020.100533

32. La Scola B, Le Bideau M, Andreani J, et al. Viral RNA load as determined by cell culture as a management tool for discharge of SARS-CoV-2 patients from infectious disease wards. European Journal of Clinical Microbiology \& Infectious Diseases 2020;39(6):1059-61. doi: 10.1007/s10096-020-03913-9

33. Prevention. KCfDCa. Findings from investigation and analysis of re-positive cases 2020

34. Santarpia JL, Rivera DN, Herrera V, et al. Aerosol and Surface Transmission Potential of SARS-CoV-2. medRxiv 2020:2020.03.23.20039446. doi: 10.1101/2020.03.23.20039446

35. Zhou J, Otter JA, Price JR, et al. Investigating SARS-CoV-2 surface and air contamination in an acute healthcare setting during the peak of the COVID-19 pandemic in London. Clinical Infectious Diseases 2020 doi: $10.1093 / \mathrm{cid} / \mathrm{ciaa905}$

36. Ahn JY, An S, Sohn Y, et al. Environmental contamination in the isolation rooms of COVID-19 patients with severe pneumonia requiring mechanical ventilation or high-flow oxygen therapy. Journal of Hospital Infection doi: 10.1016/j.jhin.2020.08.014

37. Yuan CA-O, Zhu H, Yang YA-OX, et al. Viral loads in throat and anal swabs in children infected with SARSCoV-2. (2222-1751 (Electronic))

38. Andersson M, Arancibia - Carcamo CV, Auckland K, et al. SARS-CoV-2 RNA detected in blood samples from patients with COVID-19 is not associated with infectious virus. medRxiv 2020:2020.05.21.20105486. doi: 10.1101/2020.05.21.20105486

39. Borczuk AC, Salvatore SP, Seshan SV, et al. COVID-19 pulmonary pathology: a multi-institutional autopsy cohort from Italy and New York City. Modern Pathology 2020 doi: 10.1038/s41379-020-00661-1

40. Yu HW, Hussain M, Afzal M, et al. Use of mind maps and iterative decision trees to develop a guidelinebased clinical decision support system for routine surgical practice: case study in thyroid nodules. (1527-974X (Electronic))

41. Lesho E, Reno L, Newhart D, et al. Temporal, Spatial, and Epidemiologic Relationships of SARS-CoV-2 Gene Cycle Thresholds: A Pragmatic Ambi-directional Observation. Clinical Infectious Diseases 2020 doi: $10.1093 /$ cid/ciaa1248

42. Cevik M, Tate M, Lloyd O, et al. SARS-CoV-2, SARS-CoV-1 and MERS-CoV viral load dynamics, duration of viral shedding and infectiousness: a living systematic review and meta-analysis. medRxiv 2020:2020.07.25.20162107. doi: 10.1101/2020.07.25.20162107

43. Rhee C, Kanjilal S, Baker M, et al. Duration of SARS-CoV-2 Infectivity: When is it Safe to Discontinue Isolation? Clinical Infectious Diseases 2020 doi: 10.1093/cid/ciaa1249

44. Tom MR, Mina MJ. To Interpret the SARS-CoV-2 Test, Consider the Cycle Threshold Value. Clinical Infectious Diseases 2020 doi: 10.1093/cid/ciaa619

45. Henderson DK, Weber DJ, Babcock H, et al. The perplexing problem of persistently PCR-positive personnel. Infection Control \& Hospital Epidemiology 2020:1-2. doi: 10.1017/ice.2020.343 [published Online First: 2020/07/20]

46. Bin SY, Heo JY, Song M-S, et al. Environmental Contamination and Viral Shedding in MERS Patients During MERS-CoV Outbreak in South Korea. Clinical Infectious Diseases 2015;62(6):755-60. doi: 10.1093/cid/civ1020

47. Lin W-HW, Kouyos RD, Adams RJ, et al. Prolonged persistence of measles virus RNA is characteristic of primary infection dynamics. Proceedings of the National Academy of Sciences 2012;109(37):1498994. doi: $10.1073 /$ pnas. 1211138109

48. Owusu M, Annan A, Corman VM, et al. Human Coronaviruses Associated with Upper Respiratory Tract Infections in Three Rural Areas of Ghana. PLOS ONE 2014;9(7):e99782. doi: 10.1371/journal.pone.0099782

49. Hodinka RL. Point: is the era of viral culture over in the clinical microbiology laboratory? J Clin Microbiol 2013;51(1):2-4. doi: 10.1128/JCM.02593-12 [published Online First: 2012/10/10]

50. Matheeussen V, Corman VM, Donoso Mantke $O$, et al. International external quality assessment for SARS-CoV-2 molecular detection and survey on clinical laboratory preparedness during the COVID- 
medRxiv preprint doi: https://doi.org/10.1101/2020.08.04.20167932; this version posted September 29, 2020. The copyright holder for this preprint (which was not certified by peer review) is the author/funder, who has granted medRxiv a license to display the preprint in perpetuity.

It is made available under a CC-BY-NC-ND 4.0 International license .

Viral cultures for COVID-19 infectivity assessment - a systematic review

In: Analysis of the Transmission Dynamics of COVID-19: An Open Evidence Review 19 pandemic, April/May 2020. Eurosurveillance 2020;25(27):2001223. doi: doi:https://doi.org/10.2807/1560-7917.ES.2020.25.27.2001223

51. Binnicker MA-O. Challenges and Controversies Related to Testing for COVID-19. LID - JCM.01695-20 [pii] LID - 10.1128/JCM.01695-20 [doi]. (1098-660X (Electronic))

52. Laboratory support for COVID-19 in the EU/EEA. Testing for SARS-CoV-2 virus European Centre for Disease Prevention and Control. 2020

53. Byrne AW, McEvoy D, Collins AB, et al. Inferred duration of infectious period of SARS-CoV-2: rapid scoping review and analysis of available evidence for asymptomatic and symptomatic COVID-19 cases. BMJ Open 2020;10(8):e039856. doi: 10.1136/bmjopen-2020-039856

54. Jansen RR, Wieringa J, Koekkoek SM, et al. Frequent Detection of Respiratory Viruses without Symptoms: Toward Defining Clinically Relevant Cutoff Values. J Clin Microbiol 2011;49(7):2631-36. doi: $10.1128 / \mathrm{jcm} .02094-10$

55. Yong Z, Cao C, Shuangli Z, et al. Isolation of 2019-nCoV from a Stool Specimen of a LaboratoryConfirmed Case of the Coronavirus Disease 2019 (COVID-19). China CDC Weekly 2020;2(8):123-24. doi: $10.46234 / \mathrm{ccdcw} 2020.033$

56. Xiao F, Tang M, Zheng X, et al. Evidence for Gastrointestinal Infection of SARS-CoV-2. (1528-0012 (Electronic))

57. Kim J-M, Kim HM, Lee EJ, et al. Detection and Isolation of SARS-CoV-2 in Serum, Urine, and Stool Specimens of COVID-19 Patients from the Republic of Korea. Osong Public Health Res Perspect 2020;11(3):112-17. doi: 10.24171/j.phrp.2020.11.3.02 
medRxiv preprint doi: https://doi.org/10.1101/2020.08.04.20167932; this version posted September 29, 2020. The copyright holder for this preprint (which was not certified by peer review) is the author/funder, who has granted medRxiv a license to display the preprint in perpetuity.

It is made available under a CC-BY-NC-ND 4.0 International license .

Viral cultures for COVID-19 infectivity assessment - a systematic review

In: Analysis of the Transmission Dynamics of COVID-19: An Open Evidence Review

\section{Figure 1 - PRISMA 2009 Flow Diagram}

\section{1}

542

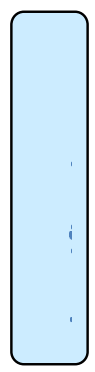

$$
\begin{aligned}
& \text { Records identified through } \\
& \text { database searching } \\
& (n=144)
\end{aligned}
$$

Additional records identified through other sources ( $n=1$, unpublished not included, $n=1$ through correspondence)

Records after duplicates removed

$$
(n=145)
$$
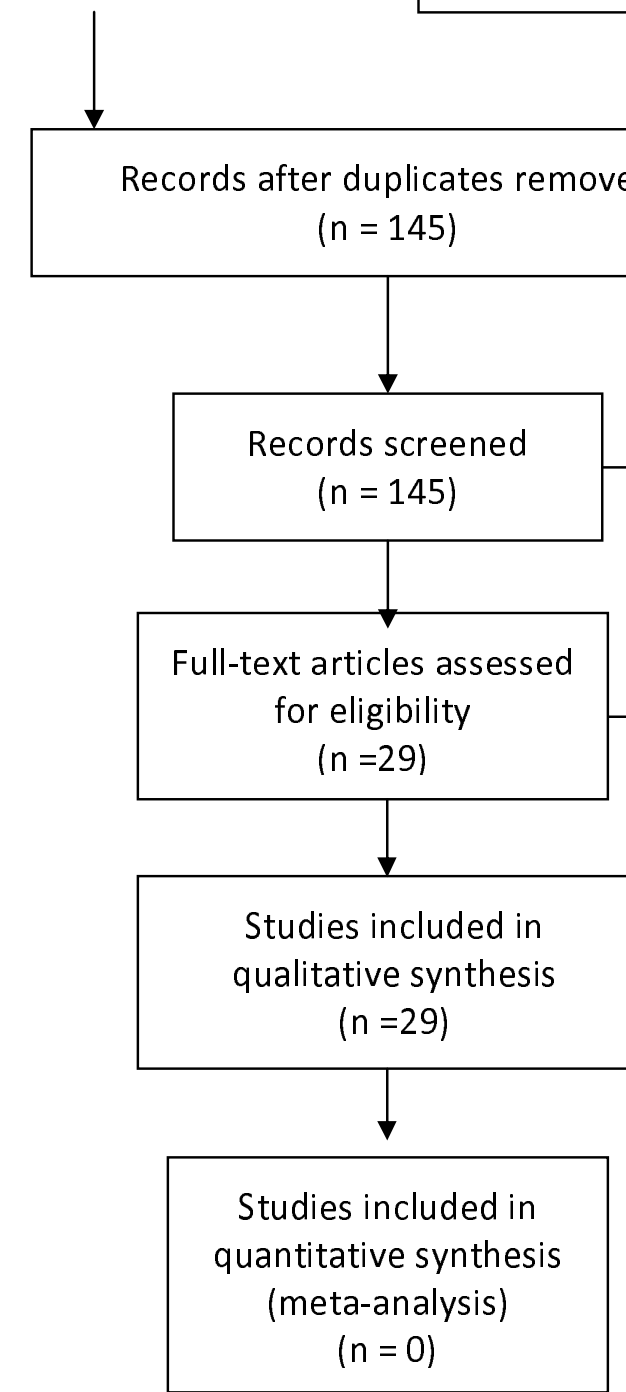
Viral cultures for COVID-19 infectivity assessment - a systematic review

In: Analysis of the Transmission Dynamics of COVID-19: An Open Evidence Review

\begin{tabular}{|c|c|c|c|c|c|c|}
\hline Serial & Study & Samples (source) & $\begin{array}{l}\text { Samples (n) } \\
\text { [SST] }\end{array}$ & Culture methods & Culture Positive & Additional notes \\
\hline 1. & Bullard $^{4}$ & $\begin{array}{l}\text { Nasopharyngeal } \\
\text { (NP) or endotracheal } \\
\text { (ETT) from COVID- } \\
19 \text { patients (mean } \\
\text { age } 45 \text { years) }\end{array}$ & $\begin{array}{l}90 \text { [0 to } 7 \\
\text { days] }\end{array}$ & $\begin{array}{l}\text { NP swabs and ETT specimens in viral } \\
\text { transport media were stored at } 4^{\circ} \mathrm{C} \text { for } 24- \\
72 \text { hours until they were tested for the } \\
\text { presence of SARS-CoV-2 RNA using real- } \\
\text { time RT-PCR targeting a } 122 \text { nt portion of } \\
\text { the Sarbecovirus envelope gene (E gene). } \\
\text { Dilutions were placed onto the Vero cells } \\
\text { in triplicate and incubated at } 37^{\circ} \mathrm{C} \text { with } 5 \% \\
\mathrm{CO} 2 \text { for } 96 \text { hours. Following incubation of } \\
4 \text { days, cytopathic effect was evaluated } \\
\text { under a microscope and recorded. }\end{array}$ & 26 & $\begin{array}{l}\text { The range of symptoms } \\
\text { onset to negative PCT was } \\
21 \text { days. Within this period, } \\
\text { positive cultures were only } \\
\text { observed up to day } 8 \text { post } \\
\text { symptom onset }\end{array}$ \\
\hline 2. & Huang $^{5}$ & $\begin{array}{l}\text { Oropharyngeal (OP) } \\
\text { or nasopharyngeal } \\
(\mathrm{NP}) \text { swabs, or } \\
\text { sputum (SP) }\end{array}$ & $\begin{array}{l}60 \text { specimens } \\
\text { from } 50 \text { cases } \\
{[3,4 \text { days }} \\
\text { mean but see } \\
\text { table } 1 \text { for } \\
\text { freeze thaw } \\
\text { cycles delays] }\end{array}$ & $\begin{array}{l}\text { SARS-CoV-2 cDNA was prepared using } \\
\text { RNA extracted from the specimens of the } \\
\text { first patient with confirmed COVID- } 19 \text {. RT } \\
\text { was performed using the MMLV Reverse } \\
\text { transcription kit. } \\
\text { All procedures for viral culture were } \\
\text { conducted in a biosafety level- } 3 \text { facility. } \\
\text { Vero-E } 6 \text { and MK-2 (ATCC) cells were } \\
\text { maintained in a virus culture medium and } \\
\text { the cells were maintained in a } 37^{\circ} \mathrm{C} \\
\text { incubator with daily observations of the } \\
\text { cytopathic effect. }\end{array}$ & $\begin{array}{l}12 \mathrm{OP}, 9 \mathrm{NP} \text { and } \\
\text { two from SP } \\
\text { specimens were } \\
\text { culturable }\end{array}$ & $\begin{array}{l}\text { Specimens with high copy } \\
\text { numbers of the viral } \\
\text { genome, indicative of higher } \\
\text { viral load, were more likely } \\
\text { to be culturable. }\end{array}$ \\
\hline 3. & $\underline{\text { Jeong }}^{11}$ & $\begin{array}{l}\text { Naso/oropharyngeal } \\
\text { swabs, saliva, urine, } \\
\text { and stool }\end{array}$ & 5 patients & $\begin{array}{l}\text { Specimens positive by qPCR were } \\
\text { subjected to virus isolation in Vero cells. } \\
\text { Urine and stool samples were inoculated } \\
\text { intranasally in ferrets and they evaluated } \\
\text { the virus titers in nasal washes on } 2,4,6 \text {, } \\
\text { and } 8 \text { days post-infection (dpi). } \\
\text { Immunofluorescence antibody assays } \\
\text { were also done. }\end{array}$ & $\begin{array}{l}\text { Naso/ oropharyngeal } \\
\text { saliva, urine and } \\
\text { stool } \\
\text { Samples were } \\
\text { collected between } \\
\text { days } 8 \text { to } 30 \text { of the } \\
\text { clinical course. } \\
\text { Viable SARS-CoV-2 } \\
\text { was isolated from } 1 \\
\text { naso / } \\
\text { oropharyngeal swab. } \\
\text { Ferrets inoculated }\end{array}$ & $\begin{array}{l}\text { Viral loads in urine, saliva, } \\
\text { and stool samples were } \\
\text { almost equal to or higher } \\
\text { than those in naso / } \\
\text { oropharyngeal swabs. After } \\
\text { symptom resolution, } \\
\text { patients shed viable virus in } \\
\text { their saliva and urine up to } \\
\text { day } 15 \text { of illness. }\end{array}$ \\
\hline
\end{tabular}


Viral cultures for COVID-19 infectivity assessment - a systematic review

\begin{tabular}{|c|c|c|c|c|c|c|}
\hline & & & & & $\begin{array}{l}\text { with patient urine or } \\
\text { stool were infected. } \\
\text { SARS-CoV-2 was } \\
\text { isolated from the } \\
\text { nasal washes of the } \\
2 \text { urine-treated } \\
\text { ferrets and one } \\
\text { stool-treated ferret }\end{array}$ & \\
\hline 4. & $\underline{\operatorname{Qian}}^{20}$ & $\begin{array}{l}\text { Rectal tissue } \\
\text { obtained from a } \\
\text { surgical procedure } \\
\text { was available. }\end{array}$ & $\begin{array}{l}1 \text { [ } 1 \text { to } 3 \text { days } \\
\text { post op] }\end{array}$ & $\begin{array}{l}\text { Ultrathin sections of tissue fixed in epoxy } \\
\text { resin on formvar-coated copper grids were } \\
\text { observed under electron microscope } \\
\text { under } 200 \mathrm{kV} \text {. Immunohistochemical } \\
\text { staining was used to establish expression } \\
\text { and distribution of SARS-CoV-2 antigen. }\end{array}$ & 1 & $\begin{array}{l}\text { No culture performed. } \\
\text { Visualisation of virions in } \\
\text { rectal tissue and detection } \\
\text { of SARS-CoV-2 antigen in } \\
\text { the rectal tissue. }\end{array}$ \\
\hline 5. & $\underline{\text { Wang }}^{12}$ & $\begin{array}{l}\text { Bronchoalveolar } \\
\text { fluid, sputum, feces, } \\
\text { blood, and urine } \\
\text { specimens from } \\
\text { hospital in-patients } \\
\text { with COVID-19 }\end{array}$ & $\begin{array}{l}4 \text { fecal } \\
\text { samples with } \\
\text { sufficiently } \\
\text { high copy } \\
\text { numbers from } \\
1,070 \\
\text { specimens } \\
\text { collected from } \\
205 \text { patients } \\
\text { with COVID-19 } \\
\text { (mean age of } \\
44 \text { years and } \\
68 \% \text { male } \\
{[1 \text { to } 3 \text { days }} \\
\text { from hospital } \\
\text { admission] }\end{array}$ & $\begin{array}{l}\text { rRT-PCR targeting the open reading } \\
\text { frame 1ab gene of SARS-CoV-2; cycle } \\
\text { threshold values of rRT-PCR were used } \\
\text { as indicators of the copy number of } \\
\text { SARS-CoV-2 RNA in specimens with } \\
\text { lower cycle threshold values } \\
\text { corresponding to higher viral copy } \\
\text { numbers. A cycle threshold value less } \\
\text { than } 40 \text { was interpreted as positive for } \\
\text { SARS-CoV-2 RNA. Four SARS-CoV-2 } \\
\text { positive fecal specimens with high copy } \\
\text { numbers were cultured, and then electron } \\
\text { microscopy was performed to detect live } \\
\text { virus. }\end{array}$ & $\begin{array}{l}4 \text { viewed by electron } \\
\text { microscope }\end{array}$ & $\begin{array}{l}\text { The details of how the } 4 \\
\text { samples were cultured were } \\
\text { not reported. } \\
\text { The patients did not have } \\
\text { diarrhoea. }\end{array}$ \\
\hline 6. & $\underline{\text { Xiao F, Sun J }}{ }^{13}$ & $\begin{array}{l}\text { Serial feces samples } \\
\text { collected from } 28 \\
\text { hospitalised COVID- } \\
19 \text { patients: } 3 \\
\text { samples from } 3 \\
\text { RNA-positive } \\
\text { patients were tested } \\
\text { for possible viral }\end{array}$ & $\begin{array}{l}3 \text {, one patient } \\
\text { admitted day } 7 \\
\text { post onset }\end{array}$ & $\begin{array}{l}\text { Inoculation of Vero } 6 \text { cells. Cycle } \\
\text { threshold values for the fecal sample were } \\
23.34 \text { for the open reading frame } 1 \text { lab } \\
\text { gene and } 20.82 \text { for the nucleoprotein } \\
\text { gene. A cytopathic effect was visible in } \\
\text { Vero E cells } 2 \text { days after a second-round } \\
\text { passage. The researchers negatively } \\
\text { stained culture supernatant and visualized }\end{array}$ & $\begin{array}{l}2 / 3 \text { (infectious virus } \\
\text { was present in } \\
\text { faeces from two } \\
\text { cases) }\end{array}$ & $\begin{array}{l}\text { Selection of samples is not } \\
\text { entirely clear. }\end{array}$ \\
\hline
\end{tabular}


Viral cultures for COVID-19 infectivity assessment - a systematic review

In: Analysis of the Cridence Review

\begin{tabular}{|c|c|c|c|c|c|c|}
\hline & & culture. & & $\begin{array}{l}\text { by transmission electron microscopy. Viral } \\
\text { particles that were visible were spherical } \\
\text { and had distinct surface spike protein } \\
\text { projections, consistent with a previously } \\
\text { published SARS-CoV2 image. }\end{array}$ & & \\
\hline 7. & $\underline{\text { Arons }}^{23}$ & $\begin{array}{l}\text { nasopharyngeal and } \\
\text { oropharyngeal } \\
\text { swabs }\end{array}$ & $\begin{array}{l}46 \text { rRT-PCR- } \\
\text { positive } \\
\text { specimens } \\
\text { [For } \\
\text { asymptomtic } \\
\text { median } 4 \text { days, } \\
\text { Ct 23.1] }\end{array}$ & $\begin{array}{l}\text { All rRT-PCR positive samples shipped to } \\
\text { USA CDC for viral culture using Vero- } \\
\text { CCL- } 81 \text { cells. Cells showing cytopathic } \\
\text { effects were used for SARS-CoV- } 2 \text { rRT- } \\
\text { PCR to confirm isolation and viral growth } \\
\text { in culture. }\end{array}$ & $\begin{array}{l}31 \text { [no relation to } \\
\text { symptoms presence. } \\
\text { Culturable virus } \\
\text { isolated from } 6 \text { days } \\
\text { before to } 9 \text { days } \\
\text { after symptom } \\
\text { onset] }\end{array}$ & \\
\hline 8. & $\underline{\text { La Scola }}^{32}$ & $\begin{array}{l}\text { Naso pharyngeal } \\
\text { swabs or sputum } \\
\text { samples } \\
\text { Only Naso } \\
\text { pharyngeal samples } \\
\text { from the subsequent } \\
\text { Jaafar et al letter. }\end{array}$ & $\begin{array}{l}183 \text { (4384 } \\
\text { samples from } \\
3466 \text { patients) } \\
\text { [not reported] }\end{array}$ & $\begin{array}{l}\text { From } 1,049 \text { samples, } 611 \text { SARS-CoV-2 } \\
\text { isolates were cultured. } 183 \text { samples } \\
\text { testing positive by RT-PCR ( } 9 \text { sputum } \\
\text { samples and } 174 \text { nasopharyngeal swabs) } \\
\text { from } 155 \text { patients, were inoculated in cell } \\
\text { cultures. SARS-CoV- } 2 \text {. RNA rtPCR } \\
\text { targeted the E gene. Nasopharyngeal } \\
\text { swab fluid or sputum sample were filtered } \\
\text { and then inoculated in Vero E } 6 \text { Cells. All } \\
\text { samples were inoculated between } 4 \text { and } \\
10 \mathrm{~h} \text { after sampling and kept at }+4^{\circ} \mathrm{C} \\
\text { before processing. After centrifugation } \\
\text { they were incubated at } 37^{\circ} \mathrm{C} \text {. They were } \\
\text { observed daily for evidence of } \\
\text { cytopathogenic effect. Two subcultures } \\
\text { were performed weekly and scanned by } \\
\text { electron microscope and then confirmed } \\
\text { by specific RT-PCR targeting E gene. }\end{array}$ & $\begin{array}{l}\text { Of the } 183 \text { samples } \\
\text { inoculated in the } \\
\text { studied period of } \\
\text { time, } 129 \text { led to virus } \\
\text { isolation. Of these } \\
124 \text { samples had } \\
\text { detectable } \\
\text { cytopathic effect } \\
\text { between } 24 \text { and } 96 \\
\text { h } \\
\text { The letter by } \\
\text { Jaafar et al adds } \\
\text { that } 1941 \text { SARS- } \\
\text { Cov-2 } 30 \text { isolate } \\
\text { cultures were } \\
\text { positive out } 3790 \\
\text { inoculated } \\
\text { samples. These } \\
\text { could be seen } \\
\text { after the first } \\
\text { inoculation or up } \\
\text { to } 2 \text { blind } \\
\text { subcultures. At at } \\
\text { Ct of }>342.6 \% \text { of } \\
\text { samples yielded a }\end{array}$ & $\begin{array}{l}\text { There was a significant } \\
\text { relationship between Ct } \\
\text { value and culture positivity } \\
\text { rate: samples with Ct values } \\
\text { of } 13-17 \text { all had positive } \\
\text { culture. Culture positivity } \\
\text { rate decreased } \\
\text { progressively according to } \\
\text { Ct values to } 12 \% \text { at } 33 \mathrm{Ct} \text {. } \\
\text { No culture was obtained } \\
\text { from samples with Ct }>34 \text {. } \\
\text { The } 5 \text { additional isolates } \\
\text { obtained after blind } \\
\text { subcultures had Ct between } \\
27 \text { and } 34 \text {, thus consistent } \\
\text { with low viable virus load. }\end{array}$ \\
\hline
\end{tabular}


Viral cultures for COVID-19 infectivity assessment - a systematic review

\begin{tabular}{|c|c|c|c|c|c|c|}
\hline & & & & & positive culture. & \\
\hline 9. & Santarpia $^{34}$ & $\begin{array}{l}\text { Windowsill and air, } \\
\text { mean } 7.3 \text { samples } \\
\text { per room. The } \\
\text { percentage of PCR } \\
\text { positive samples } \\
\text { from each room was } \\
40 \%-100 \%\end{array}$ & $\begin{array}{l}13 \text { patients } \\
\text { [days } 5 \text { to } 9 \\
\text { and day } 18 \text { of } \\
\text { isolation in a } \\
\text { quarantine } \\
\text { unit] }\end{array}$ & $\begin{array}{l}\text { Vero E6 cells were used to culture virus } \\
\text { from environmental samples. The cells } \\
\text { were cultured in Dulbeccos's minimal } \\
\text { essential medium (DMEM) supplemented } \\
\text { with heat inactivated fetal bovine serum } \\
(10 \%), \text { Penicillin } / \text { Streptomycin }(10,000 \\
\text { IU } / \mathrm{mL} \& 10,000 \mu \mathrm{g} / \mathrm{mL}) \text { and Amphotericin } \\
\text { B }(25 \mu \mathrm{gL}) \text {. }\end{array}$ & $\begin{array}{l}\text { Possibly } 2 \text { with } \\
\text { weak cyotopathic } \\
\text { effect }\end{array}$ & $\begin{array}{l}\text { Isolates were from days } 5 \\
\text { and } 8 \text { of occupancy of } \\
\text { hospital/isolation rooms }\end{array}$ \\
\hline 10. & Wölfel $^{14}$ & $\begin{array}{l}\text { Saliva, nasal swabs, } \\
\text { urine, blood and } \\
\text { stool }\end{array}$ & $\begin{array}{l}9 \text { patients [ } 2 \\
\text { to } 4 \text { days] }\end{array}$ & $\begin{array}{l}\text { The average virus RNA load was } 6.76 \times \\
105 \text { copies per the whole swab until day } \\
5 \text {, and the maximum load was } 7.11 \times 108 \\
\text { copies per swab. The last swab sample } \\
\text { that tested positive was taken on day } 28 \\
\text { after the onset of symptoms. }\end{array}$ & $\begin{array}{l}\text { Yes in respiratory } \\
\text { samples, and } \\
\text { indicative in stool }\end{array}$ & \\
\hline 11. & $\begin{array}{l}\text { Kujawski }^{15} \\
\text { (for The COVID- }^{19} \text { Investigation } \\
\text { Team) }\end{array}$ & $\begin{array}{l}\text { Nasopharyngeal } \\
\text { (NP), oropharyngeal } \\
\text { (OP), stool, serum } \\
\text { and urine } \\
\text { specimens }\end{array}$ & $\begin{array}{l}9 \text { from } 9 \\
\text { patients }\end{array}$ & $\begin{array}{l}\text { SARS-CoV-2 real-time PCR with reverse } \\
\text { transcription (rRT-PCR) cycle threshold } \\
\text { (Ct) values of virus isolated from the first } \\
\text { tissue culture passage were } 12.3 \text { to } 35.7 \\
\text { and for one patient, virus isolated from } \\
\text { tissue culture passage } 3 \text { had a titer of } \\
7.75\left\llcorner\times\left\llcorner 10^{6}\llcorner\text { median tissue culture }\right.\right. \\
\text { infectious dose per ml; these data were } \\
\text { likely more reflective of growth in tissue } \\
\text { culture than patient viral load. }\end{array}$ & $\begin{array}{l}9 \text { (including two } \\
\text { non- hospitalised) }\end{array}$ & $\begin{array}{l}\text { Viable SARS-CoV-2 was } \\
\text { cultured at day } 9 \text { of illness } \\
\text { (patient 10), but was not } \\
\text { attempted on later } \\
\text { specimens. SARS-CoV-2 } \\
\text { rRT-PCR Ct values of virus } \\
\text { isolated from the first tissue } \\
\text { culture passage were } 12.3 \\
\text { to } 35.7 \text {. } \\
\text { Mean Ct values in positive } \\
\text { specimens were } 17.0 \text { to } \\
39.0 \text { for NP, } 22.3 \text { to } 39.7 \text { for } \\
\text { OP and } 24.1 \text { to } 39.4 \text { for } \\
\text { stool. All blood and urine } \\
\text { isolates were negative. } \\
\text { Ct values of upper } \\
\text { respiratory tract specimens } \\
\text { were lower in the first week } \\
\text { of illness than the second in } \\
\text { most patients, low Ct } \\
\text { values continued into the } \\
\text { second and third week of }\end{array}$ \\
\hline
\end{tabular}


Viral cultures for COVID-19 infectivity assessment - a systematic review

\begin{tabular}{|c|c|c|c|c|c|c|}
\hline & & & & & & illness. \\
\hline 12. & Zhang $^{55}$ & Stool & $\begin{array}{l}\text { Unknown [not } \\
\text { reported] }\end{array}$ & $\begin{array}{l}\text { Vero cells were used for viral isolation } \\
\text { from stool samples of Covid- } 19 \text { patients. A } \\
2019 \text {-nCoV strain was isolated from a } \\
\text { stool specimen of a laboratory-confirmed } \\
\text { COVID-19 severe pneumonia case, who } \\
\text { experienced onset on January } 16,2020 \\
\text { and was sampled on February } 1,2020 \text {. } \\
\text { The interval between sampling and onset } \\
\text { was } 15 \text { days. The full-length genome } \\
\text { sequence indicated that the virus had } \\
\text { high-nucleotide similarity ( } 99.98 \% \text { ) to that } \\
\text { of the first isolated novel coronavirus } \\
\text { isolated from Wuhan, China. In the Vero } \\
\text { cells, viral particles with typical } \\
\text { morphology of a coronavirus could be } \\
\text { observed under the electron microscope. }\end{array}$ & 1 & $\begin{array}{l}\text { We do not know what } \\
\text { influenced successful virus } \\
\text { culture e.g. methods } \\
\text { optimal, or concentration of } \\
\text { virus optimal. More } \\
\text { information needed. }\end{array}$ \\
\hline 13. & $\frac{\text { Xiao } F \text {, Tang }}{\underline{\mathrm{M}^{56}}}$ & $\begin{array}{l}\text { Esophageal, gastric, } \\
\text { duodenal, and rectal } \\
\text { tissues were } \\
\text { obtained from } 1 \\
\text { COVID-19 patients } \\
\text { by endoscopy. }\end{array}$ & $\begin{array}{l}1 \text { plus an } \\
\text { unknown } \\
\text { additional } \\
\text { number of } \\
\text { fecal samples } \\
\text { from RNA- } \\
\text { positive } \\
\text { patients. } \\
\text { [not reported] }\end{array}$ & $\begin{array}{l}\text { Histological staining (H\&E) as well as viral } \\
\text { receptor ACE2 and viral nucleocapsid } \\
\text { staining were performed. }\end{array}$ & $\begin{array}{l}\text { 1/1 RNA-positive } \\
\text { patient. Positive } \\
\text { staining of viral } \\
\text { nucleocapsid protein } \\
\text { was visualized in the } \\
\text { cytoplasm of gastric, } \\
\text { duodenal, and } \\
\text { rectum glandular } \\
\text { epithelial cell, but } \\
\text { not in esophageal } \\
\text { epithelium of the } 1 \\
\text { patient providing } \\
\text { these tissues. } \\
\text { Additionally, positive } \\
\text { staining of ACE2 } \\
\text { and SARS-CoV-2 } \\
\text { was also observed } \\
\text { in gastrointestinal } \\
\text { epithelium from } \\
\text { other patients who } \\
\text { tested positive for } \\
\text { SARS-CoV-2 RNA }\end{array}$ & $\begin{array}{l}\text { Total sample numbers are } \\
\text { not reported. }\end{array}$ \\
\hline
\end{tabular}


Viral cultures for COVID-19 infectivity assessment - a systematic review

In: Analysis of the Transmission Dynamics of COVID-19: An Open Evidence Review

\begin{tabular}{|c|c|c|c|c|c|c|}
\hline & & & & & $\begin{array}{l}\text { in feces, results not } \\
\text { shown. }\end{array}$ & \\
\hline 14. & $\underline{\text { Yao }}^{16}$ & $\begin{array}{l}\text { Sputum }(n=7) \text {, stool } \\
(n=3) \text { and one } \\
\text { nasopharyngeal } \\
\text { sample }\end{array}$ & $\begin{array}{l}11 \text { patients } \\
\text { admitted to } \\
\text { hospital: } 9 \\
\text { classified as } \\
\text { serious or } \\
\text { critical, } 1 \\
\text { moderate, } 1 \\
\text { mild symptoms } \\
\text { [0 to } 16 \text { days] }\end{array}$ & $\begin{array}{l}\text { The samples of the } 11 \text { patients involved in } \\
\text { this study were collected during the early } \\
\text { phase of the Covid- } 19 \text { break out in China, } \\
\text { dates ranging from } 2 \text { nd of January to the } \\
2 \text { nd of April } 2020 . \\
\text { All except one of the patients had } \\
\text { moderate or worse symptoms. Three } \\
\text { patients had co-morbidities and one } \\
\text { patient needed ICU treatment. Seven } \\
\text { patients had sputum samples, one } \\
\text { nasopharyngeal and three had stool } \\
\text { samples } \\
\text { The samples were pre-processed by } \\
\text { mixing with appropriate volume of MEM } \\
\text { medium with } 2 \% \text { FBS, Amphotericin B, } \\
\text { Penicillin G, Streptomycin and TPCK- } \\
\text { trypsin. The supernatant was collected } \\
\text { after centrifugation at } 3000 \text { rpm at room } \\
434 \text { temperature. Before infecting Vero-E6 } \\
\text { cells, all collected supernatant was filtered } \\
\text { using a } 4350.45 \mu \text { m filter to remove cell } \\
\text { debris etc. } \\
\text { Vero-E6 cells were infected with } 11 \text { viral } \\
\text { isolates and quantitatively assessed their } \\
\text { viral load at } 1,2,4,8,24 \text {, and } 48 \text { hours } \\
\text { post-infection (PI) and their viral } \\
\text { cytopathic effects (CPE) at } 48 \text { and } 72 \\
\text { hours PI and examined whether the viral } \\
\text { isolates could successfully bind to Vero- } \\
\text { E6 } 243 \text { cells as expected. Super-deep } \\
\text { sequencing of the } 11 \text { viral isolates on the } \\
\text { Novaseq } 6000 \text { platform was performed. }\end{array}$ & $\begin{array}{l}11 \text { samples taken up } \\
\text { to } 16 \text { days from } \\
\text { admission to } \\
\text { hospital. }\end{array}$ & $\begin{array}{l}\text { Cultured viruses were } \\
\text { inoculated in Vero cells. At } 8 \\
\text { hours post-infection there } \\
\text { was a significant decrease } \\
\text { in Ct value (increases in } \\
\text { viral load) for five isolates. } \\
\text { At } 24 \text { hours significant } \\
\text { decreases in the Ct values } \\
\text { for all of the viral isolates } \\
\text { were observed. } \\
\text { Mutations of the viruses are } \\
\text { also reported }\end{array}$ \\
\hline 15. & Singanayagam $^{25}$ & 324 samples: nose, & 253 positive & Vero E6 cells were inoculated with & $133(41 \%)$ samples & RT-PCR cycle threshold \\
\hline
\end{tabular}

21

www.cebm.net/evidence-synthesis 
Viral cultures for COVID-19 infectivity assessment - a systematic review

\begin{tabular}{|c|c|c|c|c|c|c|}
\hline & & $\begin{array}{l}\text { throat, combined } \\
\text { nose-and throat and } \\
\text { nasopharyngeal } \\
\text { swabs and aspirates }\end{array}$ & $\begin{array}{l}\text { case } \\
{[-10 \text { to } 60} \\
\text { days] }\end{array}$ & $\begin{array}{l}\text { clinical specimens and incubated at } 37^{\circ} \mathrm{C} \text {, } \\
5 \% \mathrm{CO}_{2} \text {. Cells were inspected for } \\
\text { cytopathic effect daily up to } 14 \text { days. } \\
\text { Presence of SARS-CoV- } 2 \text { was confirmed } \\
\text { by SARSCoV-2 nucleoprotein staining by } \\
\text { enzyme immunoassay on infected cells. }\end{array}$ & (from 111 cases) & $\begin{array}{l}\text { values correlate strongly } \\
\text { with cultivable virus i.e. } \\
\text { likelihood of infectiousness. } \\
\text { Median Ct of all } 324 \\
\text { samples was } 31.15 \text {. } \\
\text { Probability of culturing virus } \\
\text { declines to } 8 \% \text { in samples } \\
\text { with Ct }>35 \text { and to } 6 \% 10 \\
\text { days after onset and was } \\
\text { similar in asymptomatic and } \\
\text { symptomatic persons. } \\
\text { Asymptomatic persons } \\
\text { represent a source of } \\
\text { transmissible virus but there } \\
\text { is no difference in Ct values } \\
\text { and culturability by age } \\
\text { group. }\end{array}$ \\
\hline 16. & $\underline{\text { Perera }}^{26}$ & $\begin{array}{l}68 \text { specimens: } \\
\text { nasopharyngeal } \\
\text { aspirates combined } \\
\text { with throat } \\
\text { swab }(n=49), \\
\text { nasopharyngeal } \\
\text { aspirate }(n=2), \\
\text { nasopharyngeal } \\
\text { swab combined with } \\
\text { throat swab ( } n=3), \\
\text { nasopharyngeal } \\
\text { swab ( } n=2) \text {, sputum } \\
(n=11) \text { and saliva } \\
(n=1) \text {. }\end{array}$ & $\begin{array}{l}35 \text { patients, } 32 \\
\text { with mild } \\
\text { disease [ } 1 \text { to } \\
67 \text { days] }\end{array}$ & $\begin{array}{l}\text { Specimens were tested for sgRNA with } \geq 5 \\
\text { log } 10 \mathrm{~N} \text { gene copies per mL. The } \\
\text { complementary DNA obtained was } \\
\text { subjected to PCR ( } 40 \text { cycles). Vero E6 } 6 \\
\text { cells were seeded and incubated for } 24 \\
\text { hours in a } \mathrm{CO}_{2} \text { incubator. The culture } \\
\text { medium was removed and } 125 \mu \mathrm{L} \text { of the } \\
\text { clinical specimen in virus transport } \\
\text { medium diluted and was inoculated into } 2 \\
\text { wells. After } 2 \text { hours incubation in a } \mathrm{CO}_{2} \\
\text { incubator at } 37^{\circ} \mathrm{C} \text {, the plates were } \\
\text { incubated at } 37^{\circ} \mathrm{C} \text { in a } \mathrm{CO}_{2} \text { incubator. A } \\
\text { sample }(100 \mu \mathrm{L} \text { ) of supernatant was } \\
\text { sampled for a quantitative real-time RT- } \\
\text { PCR at } 0 \text { and } 72 \text { hours post inoculation. } \\
\text { At } 72 \text { hours, cells were scraped into the } \\
\text { supernatant and transferred onto fresh } \\
\text { cells in } 24-w e l l \text { plates and monitored for } \\
\text { an additional } 72 \text { hours. A final quota of } \\
\text { cells was collected for quantitative real- } \\
\text { time RT-PCR. Cells were observed for } \\
\text { cytopathic effect daily and harvested for } \\
\text { testing if } 25 \%-50 \% \text { of cells showed a }\end{array}$ & $\begin{array}{l}16 / 35 \text { at a median } \\
26 \mathrm{Ct}\end{array}$ & $\begin{array}{l}\text { Culturable SARS CoV-2 and } \\
\text { sub-genomic RNA (good } \\
\text { indicator of replication) was } \\
\text { rarely detectable beyond } 8 \\
\text { days after onset of illness } \\
\text { although virus RNA by RT- } \\
\text { PCR remained for up to } 70 \\
\text { days. }\end{array}$ \\
\hline
\end{tabular}


Viral cultures for COVID-19 infectivity assessment - a systematic review

In: Analysis of the Transmission Dynamics of COVID-19: An Open Evidence Review

\begin{tabular}{|c|c|c|c|c|c|c|}
\hline & & & & cytopathic effect. & & \\
\hline 17. & Brown $^{27}$ & $\begin{array}{l}\text { Combined viral } \\
\text { throat and nose } \\
\text { swab from each } \\
\text { participant } n=1,152\end{array}$ & $\begin{array}{l}\text { Health care } \\
\text { workers in six } \\
\text { UK hospitals }\end{array}$ & $\begin{array}{l}\text { Specimens were sent on the same day for } \\
\text { detection of SARS-CoV-2 RNA by RT- } \\
\text { PCR to the PHE national reference } \\
\text { laboratory (five hospitals) or one hospital } \\
\text { laboratory. The PHE laboratory used an } \\
\text { Applied Biosystems } 7500 \text { FAST system } \\
\text { targeting a conserved region of the SARS- } \\
\text { CoV-2 open reading frame (ORF1ab) } \\
\text { gene. The hospital laboratory used a } \\
\text { different CE-IVD kit, targeting } 3 \text { SARS- } \\
\text { CoV-2 genes (RdRp, E, and N). Both } \\
\text { PCRs had internal controls. Viral culture } \\
\text { of PHE laboratory positives was } \\
\text { attempted in Vero E6 cells with virus } \\
\text { detection confirmed by cytopathic effect } \\
\text { up to } 14 \text { days post- inoculation. }\end{array}$ & $\begin{array}{l}\text { SARS-CoV-2 virus } \\
\text { was isolated from } \\
\text { only one }(5 \%) \text { of } \\
\text { nineteen cultured } \\
\text { samples. It had a Ct } \\
\text { value of } 26.2 \text {. }\end{array}$ & $\begin{array}{l}\text { Symptoms in the past } \\
\text { month were associated with } \\
\text { threefold increased odds of } \\
\text { testing positive (aOR } 3.46 \text {, } \\
95 \% \mathrm{Cl} 1.38 \text { to } 8.67 ; \\
\mathrm{p} L=\llcorner 0.008) \text {. } \\
23 \text { of } 1,152 \text { participants } \\
\text { tested positive }(2.0 \% \text { ) with a } \\
\text { median Ct of } 35.70 \\
\text { (IQR:32.42 to } 37.57) \text {. }\end{array}$ \\
\hline 18. & L'Huillier $^{28}$ & $\begin{array}{l}\text { Nasopharyngeal } \\
\text { swabs in } 638 \\
\text { patients aged less } \\
\text { than } 16 \text { years in } \\
\text { Geneva Hospital }\end{array}$ & $\begin{array}{l}23(3.6 \%) \\
\text { tested positive } \\
\text { for SARS CoV- } \\
2-\text { median age } \\
\text { of } 12 \text { years } \\
\text { (range } 7 \text { days } \\
\text { to } 14.9 \text { years) } \\
\text { [1-4] }\end{array}$ & $\begin{array}{l}\text { Observation of cytopathic effect on days } \\
2,4 \text {, and } 6 \text { of inoculum in Vero cells in two } \\
\text { passages. }\end{array}$ & $\begin{array}{l}12(52 \% \text { of PCR } \\
\text { positive) }\end{array}$ & $\begin{array}{l}\text { Ct was around } 28 \text { for the } \\
\text { children whose samples } \\
\text { grew viable viruses }\end{array}$ \\
\hline 19. & Gniazdowski $^{29}$ & $\begin{array}{l}161 \text { probably } \\
\text { nasopharyngeal } \\
\text { specimens }\end{array}$ & $\begin{array}{l}161 \text { cases with } \\
\text { positive PCR } \\
\text { [not reported] }\end{array}$ & $\begin{array}{l}\text { Ct values were calculated of only one } \\
\text { gene target per assay: the Spike (S) gene } \\
\text { for the RealStar® SARS-CoV- } 2 \text { and the } \\
\text { nonstructural protein } 101 \text { (Nsp) } 2 \text { gene for } \\
\text { the NeuMoDx }{ }^{\mathrm{TM}} \text { SARS-CoV-2 assays. } \\
\text { Genome sequencing was carried out. } \\
\text { Incubation of the inoculum in VeroE } 6 \\
\text { cells cultured at } 37^{\circ} \mathrm{C} \text { was observed for } 4 \\
\text { days for cytopathic effect and } \\
\text { immunofluorescence used to identify viral } \\
\text { presence }\end{array}$ & $\begin{array}{l}\text { Unclear possibly } 47 \\
\text { isolates }\end{array}$ & $\begin{array}{l}\text { Positive culture was } \\
\text { associated with Ct values of } \\
18.8 \pm 3.4 \text {. Infectious viral } \\
\text { shedding occurred in } \\
\text { specimens collected up to } \\
20 \text { days after the first } \\
\text { positive result in } \\
\text { symptomatics. Mean and } \\
184 \text { median Ct values } \\
\text { associated with recoverable } \\
\text { virus were } 18.8 \pm 3.4 \text { and } \\
18.17 \text { respectively, which } \\
\text { was significantly lower than }\end{array}$ \\
\hline
\end{tabular}


Viral cultures for COVID-19 infectivity assessment - a systematic review

\begin{tabular}{|c|c|c|c|c|c|c|}
\hline & & & & & & $\begin{array}{l}\text { the mean and median } \mathrm{Ct} \\
\text { values that did not correlate } \\
\text { with infectious virus } \\
\text { recovery: } 27.1 \pm 5.7 \text { and } \\
27.5 \text { respectively. PCR } \\
\text { results should be interpreted } \\
\text { alongside symptoms }\end{array}$ \\
\hline 20. & Basile $^{30}$ & $\begin{array}{l}234 \text { samples, } 228 \\
(97 \%) \text { from the } \\
\text { upper respiratory } \\
\text { tract (sputum, naso } \\
\text { pharyngeal swabs, } \\
\text { bronchial lavage } \\
\text { from } 195 \text { individuals } \\
\text { with Covid-19. }\end{array}$ & $\begin{array}{l}\text { Samples from } \\
\text { routine } \\
\text { laboratory } \\
\text { tests or from } \\
\text { patients } \\
\text { admitted to } \\
\text { ICU or from a } \\
\text { physician } \\
\text { request } \\
\text { [mean } 4.5 \\
\text { days, } 0-18 \text {, } \\
\text { only one day to } \\
\text { day } 18 \text { ] }\end{array}$ & $\begin{array}{l}\text { Probes targets for PCR included E, RdRp, } \\
\mathrm{N}, \mathrm{M} \text {, and ORF1ab for samples from ICU } \\
\text { patients and } 1 \text { to } 4 \mathrm{E}, \mathrm{RdRp}, \mathrm{N} \text { and } \\
\text { Orf1ab for all other samples. } \\
\text { After stabilization at } 4 \text { degrees centigrade } \\
\text { samples were inoculated into Vero E6 } \\
\text { cells and incubated at } 370 \mathrm{C} \text { in } 5 \% \mathrm{CO} 2 \\
\text { for } 5 \text { days (day } 0 \text { to } 4 \text { ). Cultures were } \\
\text { observed daily for cytopathic effect (CPE). } \\
\mathrm{CPE} \text { when it occurred took place between } \\
\text { days } 2 \text { and } 4 \text {. Day } 4 \text { was chosen for } \\
\text { terminal sampling. }\end{array}$ & $\begin{array}{l}\text { Culture positivity } \\
\text { rate was } 56(24 \%) \\
\text { and significantly } \\
\text { more likely positive } \\
\text { in ICU patients } \\
\text { compared with other } \\
\text { inpatients or } \\
\text { outpatients and } \\
\text { significantly more } \\
\text { likely positive in } \\
\text { samples from } \\
\text { inpatients }\end{array}$ & $\begin{array}{l}\text { The highest } \mathrm{Ct} \text { value with a } \\
\text { successful culture was } 32 \\
\text { ( } \mathrm{N} \text { gene target). A Ct cut-off } \\
\text { of } \geq 37 \text { was not indicative of } \\
\text { viable virus }\end{array}$ \\
\hline 21. & Zhou $2020^{35}$ & $\begin{array}{l}218 \text { surface } \\
\text { samples } 31 \text { air } \\
\text { samples }\end{array}$ & $\begin{array}{l}7 \text { areas of } \\
\text { large London } \\
\text { hospital }\end{array}$ & $\begin{array}{l}\text { RT-PCR with primers and probes for the } \\
\text { envelope (E) gene. Duplicate PCR was } \\
\text { carried out and samples were considered } \\
\text { positive if both duplicates had } \mathrm{Ct}<40.4 \text {, or } \\
\text { suspect if one of the two have } \mathrm{Ct}<40.4 \\
\text { (equivalent to one genome copy. For } \\
\text { culture Vero E6 and Caco } 2 \text { cells were } \\
\text { used from air and environmental samples } \\
\text { using a method adapted from one } \\
\text { previously used to culture influenza virus. } \\
\text { On day } 0 \text { and after } 5-7 \text { days, cell } \\
\text { supernatants were collected, and RT- } \\
\text { qPCR to detect SARS-CoV-2 performed } \\
\text { as described above. Samples with at least } \\
\text { one log increase in copy numbers for the } \\
\text { E gene (reduced Ct values relative to the } \\
\text { original samples) after } 5-7 \text { days } \\
\text { propagation in cells compared with the }\end{array}$ & $\begin{array}{l}\text { No cultures were } \\
\text { positive }\end{array}$ & $\begin{array}{l}\text { The pre-defined cycle } \\
\text { threshold cut off was too } \\
\text { high }\end{array}$ \\
\hline
\end{tabular}


Viral cultures for COVID-19 infectivity assessment - a systematic review

\begin{tabular}{|c|c|c|c|c|c|c|}
\hline & & & & $\begin{array}{l}\text { starting value were considered positive by } \\
\text { viral culture. }\end{array}$ & & \\
\hline 22. & $\operatorname{Kim} 2020^{57}$ & $\begin{array}{l}\text { Unclear. Possibly } \\
323 \text { serum } 247 \text { urine } \\
\text { and } 129 \text { stool } \\
\text { samples }\end{array}$ & $\begin{array}{l}74 \text { COVID-19 } \\
\text { hospital } \\
\text { patients }\end{array}$ & $\begin{array}{l}\text { RT-PCR was performed on the target } \\
\text { genes were E and RdRp. Cell culture was } \\
\text { performed in a Level III facility by } \\
\text { inoculum into CaCo- } 2 \text { cell line after } \\
\text { stabilisation at } 4 \mathrm{C} \text { and harvested after } 5 \\
\text { days and the supernatant after } \\
\text { centrifugation was re-inoculated for } \\
\text { another } 5 \text { days and assessed with RT- } \\
\text { PCR. }\end{array}$ & $\begin{array}{l}\text { No viral growth was } \\
\text { detected in any } \\
\text { specimen despite a } \\
\text { positive RT-PCR } \\
\text { very soon after } \\
\text { admission }\end{array}$ & \\
\hline 23. & Lu $2020^{18}$ & $\begin{array}{l}87 \text { cases testing "re- } \\
\text { positive" at RT-PCR } \\
137 \text { swabs ( } 51 \\
\text { nasopharyngeal, } \\
18 \text { throat and } 68 \\
\text { anal) }\end{array}$ & $\begin{array}{l}619 \text { hospital } \\
\text { discharges of } \\
\text { which tested } \\
\text { positive after } \\
\text { discharge }\end{array}$ & $\begin{array}{l}137 \text { swabs and } 59 \text { serum samples } \\
\text { from } 70 \text { "repositive" cases to assess } \\
\text { the immunological and virologic } \\
\text { characteristics of the SARS-CoV-2 } \\
\text { "repositive" cases. From } 23 \text { January, } \\
\text { hospital dischargees followed a strict } \\
\text { isolation protocol living (for example) } \\
\text { in single dedicated hotel rooms and } \\
\text { went home only when nucleic acid } \\
\text { tests were negative on both } \\
\text { respiratory tract and digestive tract } \\
\text { samples. Samples (nasopharyngeal, } \\
\text { throat and anal swabs), were } \\
\text { collected for RT-PCR diagnosis at } 7 \\
\text { and } 14 \text { days after discharge. Culture } \\
\text { was carried out by inoculating Vero } \\
\text { E6 cells with patient sample. CPE } \\
\text { were observed daily at } 7 \text { days with a } \\
\text { second round of passage. } \\
\text { RT-PCR diagnosis was carried out on } \\
\text { RNA using three RT-PCR kits to } \\
\text { conduct nucleic acid testing, in an } \\
\text { attempt to avoid false negatives. } \\
\text { Ct varied from } 29 \text { to } 39 \text { depending on } \\
\text { gene and kit }\end{array}$ & $\begin{array}{l}\text { No cultures were } \\
\text { positive }\end{array}$ & $\begin{array}{l}\text { "Re-positive" cases are } \\
\text { unlikely to be infectious } \\
\text { as no intact RNA single } \\
\text { helix was detected or } \\
\text { viral isolated grew. } \\
\text { Prolonged detection of } \\
\text { viral RNA is a challenge } \\
\text { for public health } \\
\text { interventions targeted at } \\
\text { isolating infectious cases. } \\
\text { "Re-positive" discharged } \\
\text { cases are caused by } \\
\text { intermittent shedding of } \\
\text { cells containing remnant } \\
\text { RNA. }\end{array}$ \\
\hline
\end{tabular}


Viral cultures for COVID-19 infectivity assessment - a systematic review

\begin{tabular}{|c|c|c|c|c|c|c|}
\hline 24. & Andersson $^{38}$ & $\begin{array}{l}20 \text { RT-PCR } \\
\text { positive serum } \\
\text { samples, selected } \\
\text { at random from a } \\
\text { Covid-19 sample } \\
\text { bank, representing } \\
\text { samples from } 12 \\
\text { individual patients } \\
\text { (four individuals } \\
\text { were represented } \\
\text { at two timepoints), } \\
\text { collected at } 3 \text { to } 20 \\
\text { days following } \\
\text { onset of } \\
\text { symptoms. }\end{array}$ & $\begin{array}{l}20 \text { serum } \\
\text { samples from } \\
12 \\
\text { hospitalised } \\
\text { Covid-19 } \\
\text { patients }\end{array}$ & $\begin{array}{l}\text { Samples VC01-20 were provided } \\
\text { blinded for viral culture experiments. } \\
50 \mu \mathrm{L} \text { aliquots of samples VC1-VC20 } \\
\text { were separately added to } 2.4 \times 105 \\
\text { Vero E6 cells in } 24 \text {-well plates. Cells } \\
\text { were propagated in DMEM } \\
\text { supplemented with } 10 \% \text { FBS. Virus } \\
\text { growth assays were done in DMEM } \\
\text { supplemented with } 1 \% \text { FBS, } \\
\text { glutamine and penicillin/streptomycin, } \\
\text { according to published methods. In } \\
\text { parallel, wells of the same number of } \\
\text { cells were cultured in triplicate without } \\
\text { virus challenge but with } 50 \text { } \mu \mathrm{L} \text { control } \\
\text { serum (VC21), or in duplicate with a } \\
\text { stock of Victoria/01/2020 SARS-CoV- } \\
2 \text { passage } 4 \text { (Oxford) at calculated } \\
\text { ten-fold serial dilutions per well of } 78 \text {, } \\
7.8,0.78 \text { and } 0.078 \text { plaque forming } \\
\text { units (pfu) in } 50 \mu \mathrm{L} \text { of control serum } \\
\text { (VC21). Wells were observed daily for } \\
\text { cytopathic effects (CPE), and } 50 \mathrm{~L} \\
\text { samples were taken for vRNA } \\
\text { extraction on day } 3 \text { post-challenge. } \\
\text { On day } 4,50 \mathrm{~L} \text { aliquots of } \\
\text { supernatants from cells challenged } \\
\text { with VC01-20 were "blind passaged" } \\
\text { to fresh cells, and the remaining } \\
\text { supernatants were harvested and } \\
\text { stored separately at - } 80 \mathrm{C} \text { for future } \\
\text { analysis. After a further } 3 \text { days, CPE } \\
\text { was recorded, if any, for second } \\
\text { passage cultures. }\end{array}$ & $\begin{array}{l}0 \text { / } 20 \text { these serum } \\
\text { samples produced } \\
\text { positive viral } \\
\text { culture }\end{array}$ & Serum samples. \\
\hline 25. & Korean $\mathrm{CDC}^{33}$ & $\begin{array}{l}\text { Respiratory swab } \\
\text { samples for } \\
\text { individuals testing }\end{array}$ & 108 samples & Methods not reported & $\begin{array}{l}0 \text { / } 108 \text { respiratory } \\
\text { samples }\end{array}$ & $\begin{array}{l}\text { This report does not } \\
\text { report the laboratory }\end{array}$ \\
\hline
\end{tabular}


Viral cultures for COVID-19 infectivity assessment - a systematic review

In: Analysis of the Transmission Dynamics of COVID-19. An Open Evidence Review

\begin{tabular}{|c|c|c|c|c|c|c|}
\hline & & $\begin{array}{l}\text { positive after } \\
\text { having previously } \\
\text { tested positive, } \\
\text { then negative. }\end{array}$ & & & & methods used. \\
\hline 26. & Ahn $^{36}$ & $\begin{array}{l}\text { Air and surfaces of } \\
\text { isolation room of } 3 \\
\text { patients with } \\
\text { severe Covid } 19\end{array}$ & $\begin{array}{l}48 \text { [not } \\
\text { reported] }\end{array}$ & $\begin{array}{l}\text { Only positive samples (Ct value } \leq 35 \\
\text { for the RdRp and E genes) were } \\
\text { cultured in Vero E6 cells } 10 \text {-fold } \\
\text { dilutions of the SARS-CoV-2 } \\
\text { supernatants from the environmental } \\
\text { samples was used. The inoculated } \\
\text { cultures were grown in a humidified } \\
37^{\circ} \mathrm{C} \text { incubator with } 5 \% \text { CO2. After } 72 \\
\text { hours, areas of cell clearance with } \\
\text { crystal violet staining were used to } \\
\text { demonstrate the cytopathic effect. In } \\
\text { the presence of cytopathic effect was } \\
\text { observed, detection of nucleic acid of } \\
\text { SARS-CoV-2 by rRT-PCR in the } \\
\text { supernatant was performed to confirm } \\
\text { a successful culture. }\end{array}$ & $\begin{array}{l}\text { External surfaces } \\
\text { of intubation } \\
\text { cannulae and } \\
\text { surfaces in the } \\
\text { room of patient not } \\
\text { intubated }\end{array}$ & $\begin{array}{l}\text { No air samples grew } \\
\text { virus Ct values of } \\
\text { samples who grew virus } \\
\text { were uniformly low below } \\
30 \text { except in one case. }\end{array}$ \\
\hline 27. & Young $^{1 y}$ & $\begin{array}{l}\text { Naso pharyngeal } \\
\text { swabs, stool, fresh } \\
\text { urine }\end{array}$ & $\begin{array}{l}152 \text { of } 74 \\
\text { patients }\end{array}$ & $\begin{array}{l}\text { Material from nasopharyngeal swabs } \\
\text { was inoculated in Vero-E6 cells in a } \\
\text { Level } 3 \text { laboratory. Urine and stool } \\
\text { samples were collected and } \\
\text { transported fresh for virus culture but } \\
\text { stools were filtered before inoculation. } \\
\text { Cells were cultured at } 37 \mathrm{C} \text { for seven } \\
\text { days or less if cytopathic effect (CPE) } \\
\text { was observed by day } 4 \text { and confirmed } \\
\text { by PCR. }\end{array}$ & $\begin{array}{l}21 \text { naso } \\
\text { pharyngeal } \\
\text { specimens from } \\
19(14 \%) \text { patients }\end{array}$ & $\begin{array}{l}\text { No virus was isolated } \\
\text { when the PCR cycle } \\
\text { threshold }(\mathrm{Ct}) \text { value was } \\
>30 \text { or }>14 \text { days from } \\
\text { symptom onset. Urine } \\
\text { and stool samples at } \\
\text { admission did not grow } \\
\text { virus }\end{array}$ \\
\hline 28. & Ladhani $^{31}$ & $\begin{array}{l}\text { Naso pharyngeal } \\
\text { swabs }\end{array}$ & $\begin{array}{l}87 \\
\text { [Residents } \\
\text { post, pre and }\end{array}$ & $\begin{array}{l}\text { All SARS-CoV- } 2 \text { positive samples } \\
\text { with a Ct value of < } 35 \text { were incubated } \\
\text { on Vero E6 mammalian cells and }\end{array}$ & 87 & $\begin{array}{l}\text { Ct values } \leq 35 \\
\text { Higher Ct values (lower }\end{array}$ \\
\hline
\end{tabular}


Viral cultures for COVID-19 infectivity assessment - a systematic review

\begin{tabular}{|c|c|c|c|c|c|c|}
\hline & & & $\begin{array}{l}\text { symptomatic, } \\
5(6 \text { to } 3) \\
4(2 \text { to } 11)-7 \\
(10 \text { to } 4) . \\
\text { Staff post, } \\
\text { pre and } \\
\text { symptomatic } \\
7(9 \text { to } 4) \\
\overline{3}\left(2 \_5\right)[5 \\
(9 \text { to } 3)]\end{array}$ & $\begin{array}{l}\text { virus detection was confirmed by } \\
\text { cytopathic effect (CPE) up to } 14 \text { days } \\
\text { post-inoculation. Whole genome } \\
\text { sequencing (WGS) was carried out on } \\
\text { all RT-PCR positive samples }\end{array}$ & & $\begin{array}{l}\text { virus load) samples were } \\
\text { associated } \\
\text { with decreasing ability to } \\
\text { recover infectious virus } \\
\text { from } 100 \%(2 / 2) \\
\text { with } \mathrm{Ct}<20.00 \text { to } 17.0 \% \\
(9 / 53) \text { with } \mathrm{Ct} \\
30.00 \text { 34.99 (x2 for } \\
\text { trend, } \\
\mathrm{P}<0.001)\end{array}$ \\
\hline 29. & Borczuk ${ }^{39}$ & $\begin{array}{l}\text { Post mortem lung } \\
\text { tissue from } 68 \\
\text { elderly deaths } \\
\text { (median age } 73 \text { ) }\end{array}$ & Six & $\begin{array}{l}\text { When a cytopathic effect was seen, } \\
\text { the Vero cell culture supernatant was } \\
\text { passed to a fresh Vero cell culture } \\
\text { tube to ensure reproducibility. SARS- } \\
\text { CoV-2 in the supernatant was further } \\
\text { confirmed by RT-PCR }\end{array}$ & 6 & $\begin{array}{l}\text { No ct reported. In one } \\
\text { case virus grew on day } \\
26 \text { from symptoms kick } \\
\text { off }\end{array}$ \\
\hline
\end{tabular}

Table 1. Characteristics of included studies. Key: STT = symptom onset to test date.

confirmed by RT-PCR 
Viral cultures for COVID-19 infectivity assessment - a systematic review

In: Analysis of the Transmission Dynamics of COVID-19: An Open Evidence Review

\begin{tabular}{|c|c|c|c|c|c|}
\hline Study & $\begin{array}{l}\text { Description of methods and } \\
\text { sufficient detail to replicate }\end{array}$ & Sample sources clear & $\begin{array}{l}\text { Analysis \& reporting } \\
\text { appropriate }\end{array}$ & Is bias dealt with & Applicability \\
\hline Bullard $2020^{4}$ & Yes & Yes & yes & unclear & unclear \\
\hline Santarpia $2020^{34}$ & Yes & Yes & yes & unclear & unclear \\
\hline Wölfel $2020^{14}$ & Yes & Yes & yes & unclear & unclear \\
\hline Huang $2020^{5}$ & yes & Yes & yes & unclear & unclear \\
\hline Wang W ${ }^{12} 2020$ & No & Yes & yes & no & unclear \\
\hline Zhang Y $2020^{55}$ & Partly & Yes & yes & no & unclear \\
\hline Xiao $2020 b^{56}$ & No & Yes & yes & no & unclear \\
\hline Qian Q 2020 20 & Yes & Yes & yes & unclear & unclear \\
\hline Arons $2020^{23}$ & Yes & Yes & yes & yes & unclear \\
\hline Xiao F $2020^{13}$ & Yes & Yes & yes & no & unclear \\
\hline Kujawski $2020^{15}$ & Yes & Yes & yes & unclear & unclear \\
\hline Jeong $2020^{11}$ & Yes & Yes & yes & no & unclear \\
\hline La Scola $2020^{32}$ & Yes & Yes & yes & unclear & unclear \\
\hline Yoa H $2020^{16}$ & Yes & Yes & yes & unclear & unclear \\
\hline Singanayagam ${ }^{25}$ & Yes & No & Yes & unclear & unclear \\
\hline Perera $^{26}$ & Yes & Yes & Yes & unclear & unclear \\
\hline Brown $^{21}$ & Yes & Yes & Yes & Unclear & unclear \\
\hline Gniazdowski $^{29}$ & Yes & Yes & Yes & Unclear & unclear \\
\hline Basile $^{30}$ & Yes & Yes & Yes & Unclear & unclear \\
\hline L'Huillier $^{28}$ & Yes & Yes & Yes & Unclear & unclear \\
\hline Zhou $2020^{35}$ & Yes & Yes & Yes & Unclear & Unclear \\
\hline $\mathrm{Kim}^{5 /}$ & No & No & No & Unclear & Unclear \\
\hline
\end{tabular}

www.cebm.net/evidence-synthesis 
Viral cultures for COVID-19 infectivity assessment - a systematic review

In: Analysis of the Transmission Dynamics of COVID-19: An Open Evidence Review

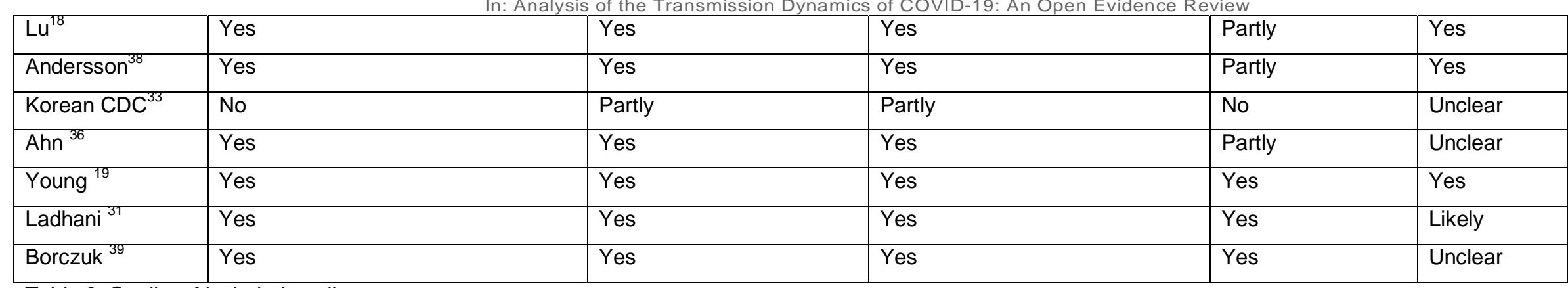

Table 2. Quality of included studies 
Viral cultures for COVID-19 infectivity assessment - a systematic review

In: Analysis of the Transmission Dynamics of COVID-19: An Open Evidence Review

Table 3. Duration of viral shedding in the included studies.

\begin{tabular}{|c|c|c|c|c|}
\hline Study & $\begin{array}{l}\text { Duration of viral shedding } \\
\text { as assessed by PCR for } \\
\text { SARS-CoV-2 RNA }\end{array}$ & $\begin{array}{l}\text { Range of } \\
\text { duration }\end{array}$ & $\begin{array}{l}\text { Median of } \\
\text { duration }\end{array}$ & Notes on clinical course \\
\hline Bullard $^{4}$ & Day 0 to day 7 at least. & NR & NR & $\begin{array}{l}\text { SARS-CoV-2 Vero cell infectivity of respiratory samples from } \\
\text { SARS-CoV-2 positive individuals was only observed for RT-PCR Ct } \\
<24 \text { and symptom onset to test of }<8 \text { days. }\end{array}$ \\
\hline Jeong $^{11}$ & $\begin{array}{l}\text { At least } 8 \text { days to at least } \\
30 \text { days }\end{array}$ & NR & NR & $\begin{array}{l}5 \text { positive-PCR patients, day } 8 \text { to day } 30 \text { after symptom onset. } \\
\text { At the time of sampling, } \\
\text { patients } 1,2,3 \text {, and } 5 \text { were on days } 8,13,11 \text {, and } 30 \text { of illness, } \\
\text { respectively, and their clinical symptoms had resolved completely. } \\
\text { Patient } 4 \text { was on day } 15 \text { of illness with a ventilator and } \\
\text { extracorporeal membrane oxygenation support. } \\
\text { All clinical specimens collected from the five patients were positive } \\
\text { for the SARS-CoV- } 2 \text { spike gene by qPCR, even though four of the } \\
\text { patients no longer displayed clinical symptoms. }\end{array}$ \\
\hline$\underline{\text { Qian }}^{20}$ & $\begin{array}{l}\text { SARS-CoV-2 RNA detected } \\
\text { day } 10 \text { to between day } 18 \\
\text { and day } 35 \text { after symptom } \\
\text { onset. }\end{array}$ & & & $\begin{array}{l}\text { Covid- } 19 \text { symptoms began on day } 3 \text { after surgery on day } 0 \text {. SARS- } \\
\text { CoV-2 PCR test done on day } 7 \text { after surgery. } \\
\text { PCR on day } 14 \text { and day } 18 \text { post-surgery were positive. } \\
\text { PCR on day } 37 \text { and day } 38 \text { after surgery were negative. } \\
\text { Patient was discharged on day } 41 \text { after surgery following the } 2 \\
\text { sequential negative PCR tests plus absence of clinical symptoms } \\
\text { and radiological abnormalities. } \\
\text { Fecal samples day } 35 \text { after discharge were negative. }\end{array}$ \\
\hline$\frac{\text { Xiao } F, \text { Sun }}{\underline{J}^{13}}$ & $\begin{array}{l}\text { Day } 7 \text { after symptom onset } \\
\text { to at least day } 28 .\end{array}$ & & & $\begin{array}{l}1 \text { patient. SARS-CoV-2 RNA PCR positive at day } 7 \text { after symptom } \\
\text { onset. }\end{array}$ \\
\hline
\end{tabular}


Viral cultures for COVID-19 infectivity assessment - a systematic review

\begin{tabular}{|c|c|c|c|c|}
\hline & & & & Patient died two weeks after final sample. \\
\hline$\underline{\text { Wölfel }}^{14}$ & $\begin{array}{l}\text { Up to day } 28 \text { after onset of } \\
\text { symptoms. }\end{array}$ & NR & NR & $\begin{array}{l}9 \text { cases. } \\
\text { All swabs taken between day } 1 \text { and day } 5 \text { were positive by PCR. } \\
\text { Virus could not be isolated from samples taken after day } 8 \text { even } \\
\text { among cases with ongoing high viral loads of approximately } 105 \\
\text { RNA copies/mL }\end{array}$ \\
\hline $\begin{array}{l}\text { Kujawski }^{15} \\
\text { (for The }^{\text {COVID-19 }} \\
\text { Investigation } \\
\text { Team) }\end{array}$ & $\begin{array}{l}\text { Duration of SARS-CoV-2 } \\
\text { detection by RT-PCR was } \\
7 \text { to } 22 \text { days }\end{array}$ & 7 to 22 days & & $\begin{array}{l}\text { First } 12 \text { identified patients in the US. Respiratory specimens } \\
\text { collected between illness days } 1 \text { to } 9 \text { (median, day } 4 \text { ) } \\
\text { All patients had SARS-CoV-2 RNA detected in respiratory } \\
\text { specimens, typically for } 2 \text { to } 3 \text { weeks after illness onset. } \\
\text { Mean duration of fever was } 9 \text { days. Two patients received a short } \\
\text { course of corticosteroids. }\end{array}$ \\
\hline $\begin{array}{l}\text { Xiao }^{56} \\
\text { Tang M }\end{array}$ & $\begin{array}{l}1 \text { to } 12 \text { days (stool } \\
\text { samples) } \\
\text { Duration of detection of } \\
\text { SARS-CoV-2 respiratory } \\
\text { samples not reported. }\end{array}$ & 1 to 12 days & NR & $\begin{array}{l}\text { Positive stool results duration ranged from } 1 \text { to } 12 \text { days. } \\
17(23 \%) \text { patients continued to have positive results in stool after } \\
\text { showing negative results in respiratory samples. }\end{array}$ \\
\hline $\begin{array}{l}\text { Singanayag } \\
\operatorname{am}^{25}\end{array}$ & $\begin{array}{l}\text { At least day } 20 \text { post } \\
\text { symptom onset, upper } \\
\text { respiratory tract swabs PCR }\end{array}$ & NR & NR & $\begin{array}{l}\text { Median duration of virus shedding as measured by viral culture was } \\
4 \text { days (IQR: } 1 \text { to } 8 \text {; range: }-13 \text { to } 12 \text {, with symptom onset dates } \\
\text { based on symptom recall) }\end{array}$ \\
\hline Perera $^{26}$ & $>30$ days in 10 patients & NR & NR & \\
\hline Brown $^{27}$ & NR & NR & NR & \\
\hline$\underset{29}{\text { Gniazdowski }}$ & $\begin{array}{l}\text { Up to } 22 \text { days in subset of } \\
29 \text { patients }\end{array}$ & $1-22$ days & NR & $\begin{array}{l}\text { Ct values reported in aggregate and for subset of } 20 \text { patients but } \\
\text { retrospective nature of specimens precluded details description }\end{array}$ \\
\hline
\end{tabular}


Viral cultures for COVID-19 infectivity assessment - a systematic review

In: Analysis of the Transmission Dynamics of COVID-19: An Open Evidence Review

\begin{tabular}{|c|c|c|c|c|}
\hline $\mathrm{Lu}^{18}$ & $\begin{array}{l}\text { Not reported in paper or } \\
\text { suppl material (no linking of } \\
\text { patient number with type of } \\
\text { sample but may be } \\
\text { available from the authors }\end{array}$ & & & \\
\hline Andersson ${ }^{38}$ & Not included in this paper & & & \\
\hline $\begin{array}{l}\text { Korean } \\
\mathrm{CDC}^{33}\end{array}$ & $\begin{array}{l}\text { Time to retesting positive } \\
\text { via PCR is reported, among } \\
\text { this specific group of } \\
\text { individuals who retested } \\
\text { positive by PCR }\end{array}$ & $\begin{array}{l}\text { On average, it } \\
\text { took } 44.9 \text { days } \\
\text { (range: } 8 \text { to } 82 \\
\text { days) from } \\
\text { initial symptom } \\
\text { onset date to } \\
\text { testing positive } \\
\text { after } \\
\text { discharge. } \\
\text { (Based on } 226 \\
\text { cases } \\
\text { symptomatic at } \\
\text { the time of } \\
\text { initial } \\
\text { confirmation) }\end{array}$ & & $\begin{array}{l}\text { This may indicate an overall duration of viral shedding, indicating } \\
\text { that shedding of RNA may detected over a long period of time and } \\
\text { inconsistently. } \\
\text { These data may not be comparable with information from studies } \\
\text { specifically observing duration of viral shedding as an outcome. }\end{array}$ \\
\hline Young $^{1 y}$ & 16.7 days & $\begin{array}{l}(95 \% \mathrm{Cl} 15.2 \\
\text { to } 18.3)\end{array}$ & & $\begin{array}{l}\text { Cessation of viral shedding by PCR occurred in } 4 \% \text { by day } 7 \text {, } \\
30 \% \text { by day } 14,78 \% \text { by day } 21 \text { and } 91 \% \text { by day } 28 \text {. There } \\
\text { were no differences by disease severity }\end{array}$ \\
\hline \multicolumn{5}{|l|}{ Ladhani $^{31}$} \\
\hline Borczuk $^{3 y}$ & $\begin{array}{l}\text { Culture positive around } 2 \\
\text { weeks of duration except } \\
\text { for one case up to } 26 \\
\text { days }\end{array}$ & NR & NR & Post mortem study \\
\hline
\end{tabular}


Viral cultures for COVID-19 infectivity assessment - a systematic review

In: Analysis of the Transmission Dynamics of COVID-19: An Open Evidence Review

Table 4: Relationship of PCR Cycle threshold and $\log { }^{10}$ copies to Positive Viral Culture

\begin{tabular}{|c|c|c|c|c|c|c|c|c|c|c|c|}
\hline \multirow[b]{2}{*}{ Study } & \multicolumn{4}{|c|}{ Sample } & \multicolumn{3}{|c|}{ Cycle Threshold } & \multicolumn{3}{|c|}{ Log ${ }^{10}$ copies } & \multirow[b]{2}{*}{ ORs for Viral Culture } \\
\hline & $\begin{array}{c}\text { RT-PCR } \\
\text { SARS- } \\
\text { CoV-2 } \\
\text { positive } \\
\text { samples } \\
\text { (n) }\end{array}$ & $\begin{array}{l}\text { Viral } \\
\text { Culture } \\
\text { growth } \\
\text { (n) }\end{array}$ & $\begin{array}{l}\text { No } \\
\text { growth } \\
\text { (n) }\end{array}$ & $\begin{array}{c}\text { Gene } \\
\text { fragment } \\
\text { sampled on } \\
\text { PCR Test }\end{array}$ & $\begin{array}{c}\text { Positive culture } \\
\text { Ct value }\end{array}$ & $\begin{array}{l}\text { Negative } \\
\text { culture Ct } \\
\text { Value }\end{array}$ & $\begin{array}{l}\text { No growth in } \\
\text { samples based } \\
\text { on } \mathrm{Ct}\end{array}$ & $\begin{array}{l}\text { Log }{ }^{10} \text { copies } \\
\text { positive } \\
\text { culture (unless } \\
\text { otherwise } \\
\text { stated) }\end{array}$ & $\begin{array}{c}\text { Log }{ }^{10} \text { copies } \\
\text { negative } \\
\text { culture }\end{array}$ & $\begin{array}{l}\text { No growth } \\
\text { based on } \\
\text { log copies }\end{array}$ & \\
\hline Bullard J $2020^{4}$ & 90 & 26 & 64 & E gene & 17 [16-18] & 27 [22-33] & $\mathrm{Ct}>24$ & & & & $\begin{array}{l}\text { OR } 0.64(95 \% \mathrm{Cl} 0.49 \text { to } \\
0.84, \mathrm{p}<0.001) \text { for every } \\
\text { one unit increase in Ct. }\end{array}$ \\
\hline \multirow{3}{*}{ Huang $2020^{5}$} & 60 & 23 & 34 & Nsp 12 & $\begin{array}{l}\text { Mean } 23.9 \pm \\
\text { SEM } 0.78\end{array}$ & $\begin{array}{l}\text { Mean } 29.26 \pm \\
\text { SEM } 0.78\end{array}$ & $\mathrm{Ct}>31.47$ & $\begin{array}{l}\text { mean } 7.37 \pm \\
\text { SEM } 0.20\end{array}$ & $\begin{array}{l}\text { Mean } 5.98 \pm \\
\text { SEM } 0.18\end{array}$ & & \\
\hline & & 23 & 37 & E & $\begin{array}{l}\text { Mean } 22.39 \pm \\
\text { SEM } 0.75\end{array}$ & $\begin{array}{l}\text { Mean } 28.92 \pm \\
\text { SEM } 0.65\end{array}$ & $\mathrm{Ct}>31.46$ & $\begin{array}{l}\text { mean } 8.21 \pm \\
\text { SEM } 0.18\end{array}$ & $\begin{array}{l}\text { Mean } 6.62 \pm \\
\text { SEM } 0.16\end{array}$ & & \\
\hline & & 21 & 31 & $\mathrm{~N}$ & $\begin{array}{l}\text { Mean } 27.29 \pm \\
\text { SEM } 0.77\end{array}$ & $\begin{array}{l}\text { Mean } 31.49 \pm \\
\text { SEM } 0.59\end{array}$ & $\mathrm{Ct}>35.2$ & $\begin{array}{l}\text { mean } 7.87 \pm \\
\text { SEM } 0.21\end{array}$ & $\begin{array}{l}\text { Mean } 6.70 \pm \\
\text { SEM } 0.17\end{array}$ & & \\
\hline $\begin{array}{l}\text { La Scola } 2020^{19} \\
\text { Jaafar 2020) }\end{array}$ & $\begin{array}{c}611 \\
(3790)\end{array}$ & 129(1941) & $\begin{array}{c}482 \\
(1849)\end{array}$ & $E$ & & & $\begin{array}{c}\mathrm{Ct} \geq 34(2,6 \% \\
\text { positives) }\end{array}$ & & & & \\
\hline Brown $\mathrm{CS}^{27}$ & 23 & 1 & 22 & RdRp, E, and & 26.16 & $\begin{array}{l}35.16 \pm \\
\text { SEM } 0.63\end{array}$ & $\mathrm{Ct}>26.2$ & & & & \\
\hline Perera $^{21}$ & 68 & 16 & 52 & $\mathrm{~N}$ & & & & $7.5^{2}$ & 3.8 & $<5.0$ & \\
\hline$\frac{\text { Singanayagam }}{2020^{22}}$ & 324 & 133 & 191 & Unclear & & & $\begin{array}{c}\mathrm{Ct}_{-}>-35 \\
\text { probability of no } \\
\text { growth was } \\
8.3 \%(95 \% \mathrm{Cl} \text { : } \\
2.8 \%-18.4 \%)\end{array}$ & & & & $\begin{array}{c}\text { OR } 0.67 \text { for each unit } \\
\text { increase in Ct value }(95 \% \\
\text { Cl: } 0.58-0.77)\end{array}$ \\
\hline Wölfel $2020^{29}$ & 45 & 9 & 36 & $\begin{array}{c}E, \\
\text { Subgenomic } \\
\text { mRNA. }\end{array}$ & & & & & & & \\
\hline L'Huillier $2020^{23}$ & $23^{4}$ & 12 & 11 & & & & & $\begin{array}{l}\text { Mean } 7.9 \times 10^{8} \\
\text { IQR } 4.7 \times 10^{6}- \\
1.0 \times 10^{9}\end{array}$ & $\begin{array}{c}\text { Mean } 5.4 \times 10^{7} \\
\text { IQR } 4.2 \times 10^{3}- \\
1.8 \times 10^{6}\end{array}$ & & \\
\hline$\frac{\text { Gniazdowski R }}{2020^{24}}$ & 132 & 47 & 85 & S, Nsp 2 & $\begin{array}{c}\text { Mean } 12.8 \pm 3.4 \\
\text { Median } 18.17\end{array}$ & $\begin{array}{c}\text { Mean } 27.1 \pm 5.7 \\
\text { Median } 27.5\end{array}$ & $\begin{array}{l}\mathrm{Ct} \geq 23 \text { yielded } \\
8.5 \% \text { of virus } \\
\text { isolates }\end{array}$ & & & & \\
\hline Basile K $2020^{25}$ & 234 & 56 & 178 & $\begin{array}{l}\text { E, RdRp, N, } \\
\text { M, and }\end{array}$ & 25.01 & 27.75 & $\begin{array}{l}\mathrm{Ct}>32 \text { with the } \\
\mathrm{N} \text { gene target }\end{array}$ & & & & \\
\hline
\end{tabular}


Viral cultures for COVID-19 infectivity assessment - a systematic review

In: Analysis of the Transmission Dynamics of COVID-19: An Open Evidence Review

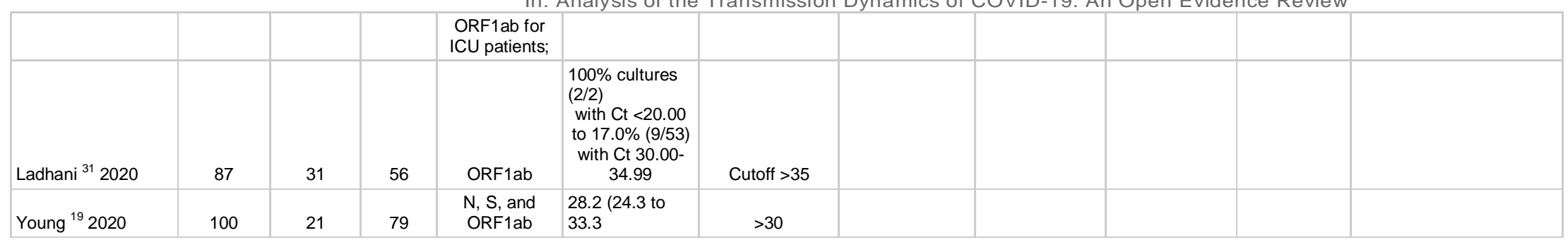

1 All above CT $(n=5) 35$ were symptomatic

2. Of the 16 culture positive specimens, $15(94 \%)$ had viral RNA load $>6 \log 10$ copies $/ \mathrm{mL}(p<0.01)$. All of them were collected within the first 8 days of illness

3. no CPE visualised but a decrease in $\mathrm{Ct}$ values between the $\mathrm{Ct}$ of the original clinical sample PCR ( $\mathrm{Ct}_{\text {sample }}$ ) and the terminal culture (day four) supernatant $\mathrm{PCR}$ (Ctculture) of $\geq 3$ (equivalent to a 1

log increase in virus quantity) i.e. $\mathrm{Ct}_{\text {sample }}-\mathrm{Ct}_{\text {cuture }} \geq 3=$ culture positive. The authors hypothesized that a $\mathrm{Ct}_{\text {sample }}$ minus $\mathrm{Ct}$ cuture $<3$ was due to residual inoculated clinical sample and not replicating

virus.

4.23 SARS-CoV-2-infected children 